\title{
Oligarchs, megafarms and land reserves: understanding land grabbing in Russia ${ }^{1}$
}

\author{
Oane Visser*, Natalia Mamonova** and Max Spoor* \\ * - Associate Professor, visser@iss.nl; ** - PhD Candidate, mamonova@iss.nl; *** - Professor, spoor@iss.nl, \\ International Institute of Social Studies, The Hague of Erasmus University Rotterdam
}

\begin{abstract}
This paper seeks to unravel the political economy of large-scale land acquisitions in post-Soviet Russia. Russia falls neither in the normal category of 'investor' countries, nor in the category of 'target' countries. Russia has large 'land reserves', since in the 1990s much fertile land was abandoned. We analyse how particular Russia is with regards to the common argument in favour of land acquisitions, namely that land is available, unused or even unpopulated. With rapid economic growth, capital of Russian oligarchs in search of new frontiers, and the 2002 land code allowing land sales, land began to attract investment. Land grabbing expands at a rapid pace and in some cases, it results in dispossession and little or no compensation. This paper describes different land acquisitions strategies and argues that the share-based land rights distribution during the 1990s did not provide security of land tenure to rural dwellers. Emerging rural social movements try to form countervailing powers but with limited success. Rich land owners easily escape the implementation of new laws on controlling underutilized land, while there is a danger that they enable eviction with legal measures of rural dwellers. In this sense Russia appears to be a 'normal' case in the land grab debate.
\end{abstract}

Keywords: land grabbing; Russia; agroholdings; dispossession; land reserves; land reform

\section{Introduction}

The topic of large-scale land acquisition or 'land grabbing' has recently received growing attention among academics and policy makers (von Braun and Meinzen-Dick 2009, World Bank 2010a, HLPE 2011). Specifically, land grabbing has been studied in Africa (Cotula et al. 2009, Hall 2012), South-East Asia (Julia and White 2012), Latin America (Zoomers 2010, Borras et al. 2012) and China (Ding 2007, Hofman and Ho 2012). However, until now, the vast land masses of the former Soviet Union constitute a blank spot in the global investigation of land grabbing, as noted by Visser and Spoor (2011a) in a first overview of land grabbing in this region. The current paper builds on this with a more elaborate investigation of land relations and mechanisms of land acquisition, focusing on the case of Russia. Furthermore this paper is based on recent fieldwork, whereas Visser and Spoor (2011a) was predominantly based on media and web research. The current literature on land grabbing predominantly tries to map the magnitude and speed of land grabbing, the main types of countries or private

\footnotetext{
${ }^{1}$ This article is published in Journal of Peasant Studies. To cite it: Visser, O., N. Mamonova and M.Spoor (2012) 'Oligarchs, megafarms and land reserves: understanding land grabbing in Russia', Journal of Peasant Studies 39:3-4, pp.899-931 DOI:10.1080/03066150.2012.675574
} 
actors involved worldwide, and the general drivers of the global land grab. Following new research lines advocated by Borras et al. (2011, p.211) this paper pursues a closer look at the actors involved, their motivations and interests, and especially the mechanisms through which large-scale land deals are enacted. The link with the global land grab debate will be made in particular through analyzing the 'availability of land' and what this means in the Russian context.

Russia is the largest agricultural producer in post-Soviet Eurasia, and worldwide it is one of the countries with the largest land reserves for agricultural production, as well as the country with the potential for the largest increase in grain production worldwide (World Bank 2010a). Russia has one of the highest levels of arable land in the world, namely 0.9 hectares (ha) per capita (World Bank 2010a, b). This ratio is higher only in Canada and Australia, but these countries have less potential to increase production, as most agricultural land is being used, with high land productivity. Moreover, it is to be expected that climate change will reduce the acreage of arable land, whereas in Russia the acreage of cultivable land might expand northward, for instance. According to the World Bank, water availability will increase (5-15 percent) in the north of Russia and Kazakhstan (FAO 2011), which may offset the higher occurrence of droughts in the south of Russia (HLPE 2011, Dronin and Kirilenko 2011). Whereas most countries in the world face declining availability of agricultural and arable land per capita, in Russia the availability of land per capita has actually increased over the last two decades, because of stagnation of the population ${ }^{2}$. Moreover, a substantial amount of Russia's agricultural land was taken out of production in the 1990s. According to the president of Russia Dmitry Medvedev, the amount of unused or inefficiently used agricultural land may total 30 million ha (Wegren 2011, p.152). However, reports differ on the amount of land taken out of production (IAMO 2011, Ioffe and Nefedova 2004). This abundance of available 'unused' but often very fertile land has raised the interest of investors, not only of domestic investors (the Russian oligarchs amongst others), but also of foreign companies and governments. However, whether all of the land classified as such really is 'unused' or 'abandoned' needs further scrutiny.

The phrase 'global land grab' has become a catch-all to describe and analyze the current explosion of large-scale (trans)national commercial land transactions. Some see land grabs as a major threat to the livelihoods of the rural poor and oppose such commercial land deals. Others see them as a necessity to modernize agriculture and as an economic opportunity for the rural poor, although they are wary of corruption and negative consequences, and hence, call for improving land market governance (Borras et al. 2011). Often land grabbing has been defined as large-scale land acquisitions by foreigners (GRAIN 2008), but currently a substantial share of land grabbing is conducted by domestic investors, or by coalitions of foreign and domestic actors. Following Borras et al. (2012), we define land grabbing as 'the large-scale acquisition of land or land-related rights and resources by a corporate, non-profit or public buyer for the purposes of resource extraction geared towards external consumers (whether external simply means off-site or foreign)'. Extraction and alienation are essential to this definition rather than the type of capital invested, the intended market or the act of commodification or privatisation of land per se.

\footnotetext{
${ }^{2}$ Russia's population peaked in the early 1990s (at the time of the end of the Soviet Union) with about 148 million people in the country. Today, it is approximately 143 million. The United States Census Bureau estimates that Russia's population will decline from the current size to a mere 111 million by 2050, a loss of more than 30 million people and a decrease of more than 20 percent (Rosenberg 2012).
} 
The widespread farm restructuring and share-based land reform in Russia in the first half of the 1990s 'opened up' a huge and fertile area of land for investors in agricultural land. However, for more than a decade this sparked little interest among investors. The picture changed when Russian oligarchs and Western investors started to search for new frontiers of investment with domestic economic growth and the influx of Russian offshore capital as well as due to the global financial crisis (Jouko and Granberg 2011) $)^{3}$. Moreover, rapidly increasing local demand for livestock products (related to demand for grains) in Russia, and subsequent legal and policy changes stimulating agricultural investment, caused high demand for agricultural land. Large-scale land investments became popular among Russian and foreign companies. Foreigners are not officially allowed to acquire agricultural land in Russia. However, they do so by means of their Russian subsidiaries, which are considered as Russian domestic companies by Russian law. 'We are seeing a land grab bigger than anywhere else in the world, and it has attracted a mighty cast of characters', stated Kingsmill Bond, a chief strategist at the Moscow Brokerage firm Troika Dialog (Kandell 2009).

This current rush of investors for land (and the earlier experience with industry) raises serious concerns about the transparency, inclusiveness and fairness of land acquisitions. There is a danger of widespread dispossession of rural inhabitants who recently acquired entitlements to property in the form of land shares in the 'cosmetically' privatised, large-scale successors of the state and collective farms, which are developing into megafarms. Will land grabbing cause rural dwellers to lose their land rights, soon after they received them in the 1990s? In the absence of studies on land grabbing in the former Soviet Union, we know relatively little of the various effects.

This paper focuses on the investors in land and their strategies. However, effects of these land acquisitions for the rural population regarding land ownership (and potential dispossession) will also be addressed. We focus on the main players in the Russian land market and the strategies and mechanisms they use for land acquisition, such as deliberate bankruptcy of collective farms in order to buy their lands, the massive purchase of land shares acquisition after land law (2002), and using the inequality in power relations. Finally, the role of the Russian state vis-à-vis large-scale land acquisitions is discussed.

The paper is structured as follows. In the second section, the specificities of research on land grabbing in Russia are described, with special attention to difficulties with data collection. In the third section, it will be shown that the land rights ('shares') the population received during the restructuring of state and collective farms were rather insecure, which facilitated land grabbing later on. The fourth section investigates the magnitude of the large-scale land acquisitions in Russia, and the actors and structures behind them, such as Russian oligarchs, megafarms and foreign investors.

Section five looks at the motivations of investors and the land acquisition strategies that are used to avoid different restrictions on land sales in legal (using loopholes in Russian legislation) and illegal ways. The sixth section looks at the issue of abandoned land, land reserves and dying villages, distinguishing between discourse and reality. Section seven analyses land accumulation strategies and responses of rural dwellers attempting to counter or mitigate unfair land acquisition. In section eight the role of the Russian state in the facilitation

\footnotetext{
${ }^{3}$ The financial crisis led to temporary problems with access to finance in Russia; however, more fundamentally it stimulated, globally as well as in Russia, a major shift of capital towards the agri-food sector, and the primary sector more broadly.
} 
of land grabbing is analysed, which is often crucial. Finally, the concluding section looks at land grabbing in Russia in the years to come, arguing that it is expected to continue at great pace, and that proposed government interventions to constrain land grabbing will likely not prevent illegal land acquisitions, and might even have adverse effects.

\section{Doing research on land grabbing in Russia: data resources}

To study land grabbing empirically in Russia is complex. The information about domestic and foreign land transactions provided by Russian statistical institutions such as Rosstat and the cadastral agency Rosreestr is incomplete and provides only general information about land ownership and usage. Furthermore, the rapid increase in international transactions in agricultural land renders available information quickly outdated (Visser and Spoor 2011b). Moreover, according to Uzun et al. (2009), statistics on landholdings and land deals are collected at the agricultural enterprise level and are generally not available for agroholdings (Uzun et al. 2009), which are the crucial actors in land acquisitions. An agroholding includes a number of agricultural organisations whose controlling blocks of shares are owned by the holding company. It acts as an umbrella for the subordinated (not necessarily only agricultural) units and controls their policies and management. Agroholdings often combine agricultural production enterprises with other upstream and downstream firms in the agri-food chain, such as producers of concentrated fodder, elevators, processing units and wholesalers. As a rule, investors (both domestic and foreign) invest in Russian land via agroholdings.

There are no databases in Russia that include full information about Russian agroholdings, their capital or the acreage they control. As these agroholdings are currently the main actors in the land grabbing process, this shortcoming seriously complicates research on land grabbing in Russia. However, even with more statistical data at this level, the reliability of such data would be questionable due to the lack of transparency of Russian agroholdings and the concealed nature of much of the domestic and foreign investment that is taking place.

Therefore, in this paper we study land grabbing based on the following methods. First, through continuing our web research: gathering many dispersed pieces of information from the Russian media, reviews in web journals, and examining web pages of agroholdings and foreign investment funds operating in Russia. Second, we held in-depth interviews with leaders of some foreign and domestic agroholdings operating in Russia, government officials, rural inhabitants and representatives of emerging rural movements (Visser 2010, Visser and Mamonova 2011 ${ }^{4}$. Within the scope of this research paper we can only pay limited attention to the regional differences in land acquisitions within Russia and aim to focus on some of the general tendencies. For studies that deal extensively with regional differences we refer to the work by Pallot and Nefedova (2007) that covers a wide range of regions, as well as the work

\footnotetext{
${ }^{4}$ Most of the interviews were conducted by Mamonova and Visser in the autumn of 2010 and winter and spring of 2011 in the Moscow region. Most of the agroholdings which were included in the research have (or formerly had) foreign investment, and operate in multiple Russian regions. The paper also benefited from interviews with foreign investors conducted by Steggerda and Visser in the autumn of 2011 and winter of 2012. Michelle Steggerda is an honours student in the department of Anthropology and Development Studies, Radboud University Nijmegen. Finally, the paper uses data from interviews with domestic and foreign investors in agriculture conducted earlier by Visser in the Moscow, Rostov, Pskov and Saint Petersburg regions. Among the rural movements, Krestyanskiy Front (Peasant Front) is the largest. This movement fights for the protection of peasants' rights, in the face of land dispossession by large-scale investors.
} 
This article is published by Taylor \& Francis in the Journal of Peasant Studies on 28 May 2012, available online: http://www.tandfonline.com/doi/abs/10.1080/03066150.2012.675574\#.VeCmAPmqqko . To cite this article: Visser, 0 ., N. Mamonova and M.Spoor (2012) 'Oligarchs, megafarms and land reserves: understanding land grabbing in Russia', Journal of Peasant Studies 39:3-4, pp.899-931

of Visser (2006, 2008) and Lindner (2008), which provides a close up study of farm enterprises in three contrasting regions.

\section{Post-Soviet land reform: the political economy of insecurity}

\subsection{Post-Soviet land reform after 1991}

The Russian land reform was aimed at changing ownership of farmland from state into private property, while the dominant large state and collective farms were to be restructured towards 'individualized' production. No land restitution policy was followed as it was not possible to determine who the previous land owners were before the forced collectivisation of farms and the nationalisation of land in the 1930s. This was only done in the Baltics and in some countries of Central Europe. Moreover, the collectivisation had often been carried out together with imprisonment, deportation and killing of numerous 'rich' peasant farmers (the so-called kulaks). The various farm enlargement campaigns in the later Soviet period were accompanied by multiple relocations of rural settlements, further adding to the alienation of the rural population from their former or ancestral land. Therefore, among both policy makers and the rural population, there was no serious interest for restitution of land to the precommunist owners. Instead, land was to be distributed equally among the current rural inhabitants (World Bank 1992), although, as we will see below, this was not done in a physical sense, but through share-based entitlements to land (Spoor and Visser 2001).

In the early 1990s only one percent of the agricultural land was privately used (these were the subsidiary household plots of the employees on the state and collective farms). The other 99 percent of land belonged to the state (Poshkus 2009, p.68). This situation changed dramatically with the post-1991 land reform. Land was given to the former kolkhozes and sovkhozes (collective and state farms) for further distribution among their members in the form of paper shares. During that time investors in agriculture were not able to buy land, but they were not completely passive. Some of them waited until the end of this moratorium (2002), in the meantime making contacts with the management of attractive farms and lobbying with local authorities.

Land reform in Russia was carried out in two stages. First, in 1990 the law 'On land reform' focused on taking 10 percent of kolkhoz and sovkhoz land and transferring it to local authorities for distribution among peasants who were willing to establish a private family farm. However, at the end of 1992 there were only 50,000 private family farms that owned less than 1 percent of agricultural land. According to Poshkus (2009, p.68) problems arose due to the unwillingness of kolkhoz leadership to hand over the land to local authorities and the lack of understanding of land reform among peasants. Second, at the end of 1991 the Presidential Decree No. 323 ('On urgent measures for the implementation of land reform in the RSFSR ${ }^{5}$ ') was issued by the first Russian President Boris Yeltsin. This involved the transformation of state and collective farms into new juridical forms (mostly closed jointstock companies or CJSC) with the employees becoming 'shareholders'. Subsequently, each employee received non-land asset shares and land shares (on average three to fifteen ha) for free. However, the shares did not include real, individual ownership. The land shares that employees received were paper certificates, that substantiated their rights to unspecified land

\footnotetext{
5 The Russian Soviet Federative Socialist Republic (RSFSR) is the republic of the former Soviet Union, which after the collapse of the Soviet Union in December 1991 was renamed the Russian Federation.
} 
plots on the territory of their former state or collective (Poshkus 2009, p.68, Spoor and Visser 2001). Gustav Wetterling (Agro-Invest Group - a subsidiary of Swedish Black Earth Farming Ltd) calls this process 'semi-privatisation', meaning that peasants didn't become real owners of the land, as they only received the right to be owners (Interview, 23 September 2010, Moscow).

Ownership of such land could occur in two cases. First, the peasant transferred his/her land share to the charter capital of the restructured farm enterprise. In this case, land became property of the farm. Second, the peasant created a separate private farm, by registering the land as his/her ownership. However, private land registration required significant time and financial resources due to the highly bureaucratic system in the country. According to Poshkus (2009, p.69) the main weakness of the reform was 'the problem with the definition of land rights and their usage'. This provided a loophole facilitating future land grabbing in Russia and is increasingly generating land conflicts in the country. However, more clearly defined property rights alone would not have been a solution, as land reform took place in a situation in which markets were still in the making, political interference remained strong, and distribution of power was highly unequal (Spoor and Visser 2004).

During President Vladimir Putin's first term the Federal Law N136-FZ 'Land Code of Russian Federation' (2001) was adopted that modified property rights for land with the exception of agricultural land, and in 2002, the Federal Law N 101-FZ 'On Agricultural Land Transactions' came into force. This law specified procedures for selling agricultural land and served as a template for regional legislation (Wegren 2009b). Tamara Semenova (vicepresident of the peasant movement Krestyanskiy Front) suggests that this law 'was lobbied by a group of oligarchs who had already bought or planned to buy land. This law was worked out to legalize their purchases' (Interview, 29 September 2010, Moscow). During Putin's second term (2004-2008), Russian and foreign investors became interested in agricultural land and commenced buying land shares.

\subsection{High costs of land registration}

Land reform in Russia during the 1990s did not lead to clearly defined land rights and tenure security. According to Lerman and Shagaida (2007), most (84 percent) of the peasant farmers in the more agriculturally developed regions in Russia regarded first, complex procedures of land transactions, and second, high registration costs as major problems in the development of their farming operations. In order to register their land, peasants had (and have) to pass three organisational levels: the aforementioned district committees, cadastral chambers and registration chambers.

After this long procedure the land shares are transferable: they can be leased or sold, transferring the rights to the underlying acreage to another operator or owner. However, peasants have to spend considerable costs to pass through the entire procedure. 'Often people in remote areas do not even have money in order to formalize their land shares', as Tamara Semenova of Krestyanskiy Front stated (Interview, 29 September 2010, Moscow). First Deputy Premier Viktor Zubkov revealed in February 2009 that of the 12 million land shareholders, only 400,000 have been able to register their land plots. With the emergence of 
This article is published by Taylor \& Francis in the Journal of Peasant Studies on 28 May 2012, available online: http://www.tandfonline.com/doi/abs/10.1080/03066150.2012.675574\#.VeCmAPmqqko . To cite this article: Visser, 0 ., N. Mamonova and M.Spoor (2012) 'Oligarchs, megafarms and land reserves: understanding land grabbing in Russia', Journal of Peasant Studies 39:3-4, pp.899-931

outside investors (see next section), the weaknesses of land reform in securing land rights of the rural population have become more and more apparent ${ }^{6}$.

\section{The magnitude of land grabbing and the types of actors involved}

\subsection{Domestic investors}

In the 1990s, most Russian companies considered the agricultural sector as unprofitable and preferred to invest in other branches, while interest from foreign investors was also limited (with a few exceptions; see below). The new Russian government sharply curtailed investment in the agriculture sector (Barnes 2006) and the large farm enterprises (LFEs), successors of the kolkhozes and sovkhozes, faced severe financial difficulties.

The privatisation of oil, gas, and mineral resources and industry sectors in the early 1990s led to a rush to acquire former state enterprises. A fierce struggle for the most prized assets evolved between the Russian oligarchs and sometimes between worker collectives and oligarchs. Later, foreign investors and the Russian state (especially in the oil sector) became involved in this struggle over acquisition of property (Barnes 2006). However, as indicated above, land reform had been 'largely cosmetic', involving little more than 'changing the name plate of the farm' (Brooks et al. 1996). Comparing agrarian property transformation in the 1990s with privatisation in other sectors, Barnes wrote that:

...the struggles in the sector could also seem underwhelming, lacking even the guilty fascination provoked by the decadence of conflicts in industry. [...] Private farmers did not drive around Moscow in Mercedes cars or pull rolls of hundred-dollar bills from their pockets in casinos. Newspapers did not brim with stories of upstart speculators battling corrupt managers and organized crime bosses for control over agricultural production. Instead, the sector often seemed interesting only for its pity value $(2006,141)$.

Indeed, Russian agriculture was in dire straits (with roughly 80 percent of the farm enterprises incurring losses by the mid-1990s). The market-oriented agrarian reform took place in a period of sharp economic decline of the economy at large and drastic cuts in government spending on agriculture in particular (Wegren 2009a, 2011). In the 1990s land prices were very low and often land even had a negative value because of costs in the form of land tax and informal social obligations attached to land, such as to provide feed for private livestock of the villagers or provide social infrastructure (Visser 2006). During this period the sparse outside 'investors' (from outside the agribusiness sector) who took over farm enterprises did so often with the goal of asset stripping. Equipment and buildings were sold off, while the land was mostly left unused (Kalugina and Fadeeva 2009).

Due to the dire straits of the large farm enterprises, part of their lands ended up in the hands of creditors in order to pay off farm debts, in particular to suppliers of fuel such as the energy giants Gazprom and Lukoil (Barnes 2006, p.161). The first substantial agricultural land bank, operated by Gazprom, started when farm enterprises were unable to cover their fuel debts and had to pay back with their land. The total property of Gazprom is more than 500,000 ha. Gazprom is currently engaged in a process of selling off its agricultural land again, as the

\footnotetext{
${ }^{6}$ This large gap between the number of unregistered and registered land shares/plots indicates that there is still widespread tenure insecurity.
} 
This article is published by Taylor \& Francis in the Journal of Peasant Studies on 28 May 2012, available online: http://www.tandfonline.com/doi/abs/10.1080/03066150.2012.675574\#.VeCmAPmqqko . To cite this article: Visser, 0 ., N. Mamonova and M.Spoor (2012) 'Oligarchs, megafarms and land reserves: understanding land grabbing in Russia', Journal of Peasant Studies 39:3-4, pp.899-931

company was not successful in agribusiness due to the absence of skills and knowledge in agriculture (Uzun et al. 2009).

'Attendant with strong economic growth that ensued from 1999 through 2007, land began to be perceived as a valuable commodity from which to build wealth. Agricultural land became the new frontier for those with money' (Wegren 2009b, p.3). New changes in Russian land laws, focusing on attracting direct and indirect investments to the agricultural sector by guaranteeing private property rights on the land, gave impetus to the creation of large-scale agroholdings or megafarms at the expense of rural dwellers. In Russia most agricultural land continues to be controlled by LFEs, and since the early 2000s, a growing percentage of these are controlled by large agroholdings and corporations, previously state- and now privately owned.

According to the All-Russian Agricultural Census of 2006, private family farmers owned only 13 percent of agricultural land in Russia in 2005 and household plots accounted for less than 5 percent (Rosstat 2006, p.36). All other land is controlled by LFEs and agroholdings, both national and international, although a large share of this land is still formally in the hands of (former) employees cum shareholders ${ }^{7}$. Nearly 60 percent of agricultural land is now privately owned, but most of this land (51 percent) is represented by land shares - pieces of paper corresponding to virtual plots of specified size in an unspecified location (Lerman and Shagaida 2007). These land shares are transferable: they can be leased or sold, transferring the rights to the underlying acreage to another operator or owner. Only 6 percent of agricultural land is in the form of physically demarcated plots, (that means land shares which were actually registered by the possessor), most of it owned by individuals (household plots and peasant farms) (Lerman and Shagaida 2007).

The number of agroholdings (as well as the size of their landholdings) has rapidly increased since the early 2000s. According to the Russian Ministry of Agriculture in 2003, more than 90 agroholdings were active in 25 regions. By 2006, 319 private agroholdings were already registered (Uzun et al. 2009, p.159). By the mid-2000s in various fertile Black Earth regions, such as Belgorod, Lipetsk, Voronezh and Tambov, there was practically no 'free' land available that was not yet controlled by an agroholding (Didenko 2009). By mid-2008, according to the Institute for Agricultural Market Studies, 196 large agroholdings controlled 11.5 million ha (BEFL 2010, p.9). Of these agroholdings, 32 had landholdings of over 100,000 ha.

It is hard to say how many land transactions are conducted in Russia exactly, let alone those of specifically agricultural land. But definitely the number of land transactions is growing. In the mid-2000s about five percent of agricultural land was transacted annually (Shagaida 2005), a figure which has risen further in the last few years to at least eight percent (see Table 2) with a strong rise in the number of land deals (25 percent in 2009) between citizens and legal entities. These data of course do not include shady, unregistered deals ${ }^{8}$.

\footnotetext{
${ }^{7}$ Also, individual entrepreneurs account for about 1.5 percent of agricultural land. A small part of the land used by large-scale farm enterprises is still owned by the state.

${ }^{8}$ In 2010 the upward trend was temporary affected by the financial crisis. According to some estimates, the registered transactions in 2010 were almost a third less than during the same period before the crisis of 2008, due to problems of investors with financing land deals in context of the global financial crisis, which hit Russia hard.
} 
This article is published by Taylor \& Francis in the Journal of Peasant Studies on 28 May 2012, available online: http://www.tandfonline.com/doi/abs/10.1080/03066150.2012.675574\#.VeCmAPmqqko . To cite this article: Visser, 0 ., N. Mamonova and M.Spoor (2012) 'Oligarchs, megafarms and land reserves: understanding land grabbing in Russia', Journal of Peasant Studies 39:3-4, pp.899-931

\subsection{Foreign land acquisitions: a brief overview}

Foreign land acquisitions are clearly on the rise in Russia since the mid-2000s (Visser and Spoor 2011a), although already in the mid-1990s some Western companies attempted to enter Russian agribusiness. However, it is hard quantify foreign land acquisitions. Foreign companies are not allowed to directly buy land.

The Federal Law N136-FZ 'Land Code' (2001) prohibits ownership of agricultural land by foreign citizens and companies, as well as Russian companies with foreigners owning more than 50 percent of the shares. To avoid the application of this law, foreign investors establish Russian subsidiaries that are legally not regarded as foreign companies (a strategy which is actively promoted by the Russian government, as will be shown in a later section). According to our most recent estimates, roughly 50 foreign companies control up to an estimated 3.5 million ha of Russian agricultural land. However, accumulation of land is a highly sensitive issue for both the leasing and the hosting countries, and therefore it is likely that the process of land grabbing in post-Soviet Eurasia has advanced further than official statements and media reports suggest (Billette 2009, Visser and Spoor 2011a). In terms of the total size of the agricultural land obtained, Russia is not a top target of foreign investment, but investment by outside investors is indeed substantial and the size of average land deals, including actually implemented ones, is very large. Having access to large financial resources, foreign investors acquire the most fertile land, use modern technology to achieve high productivity, and take leading positions in regional and sometimes even national markets.

Table 2: Land Transactions (sale and lease) in Russia (2006-2009)

\begin{tabular}{|c|c|c|c|c|}
\hline & 2006 & 2007 & 2008 & 2009 \\
\hline \multicolumn{5}{|c|}{ Transactions with state and municipalities } \\
\hline Number of transactions & 3921393 & 3875650 & 3985846 & 3887691 \\
\hline Change in amount & & $-1 \%$ & $3 \%$ & $-2 \%$ \\
\hline $\begin{array}{l}\text { Amount of land (ha) in } \\
\text { transactions }\end{array}$ & 105214779 & 114622029 & 115351558 & 114018863 \\
\hline Approx ha per deal & 27 & 30 & 29 & 29 \\
\hline \multicolumn{5}{|c|}{ Transactions between citizens and companies } \\
\hline Number of transactions & 623747 & 643443 & 794792 & 996462 \\
\hline Change in amount & & $3 \%$ & $24 \%$ & $25 \%$ \\
\hline $\begin{array}{l}\text { Amount of land (ha) in } \\
\text { transactions }\end{array}$ & 1231830 & 1221829 & 2415179 & 18761609 \\
\hline Approx ha per deal & 2 & 2 & 3 & 19 \\
\hline \multicolumn{5}{|l|}{ Total transactions } \\
\hline Number of transactions: & 4545140 & 4519093 & 4780638 & 4884153 \\
\hline Change in amount & & $-1 \%$ & $6 \%$ & $2 \%$ \\
\hline Amount of land (ha) in & 106446609 & 115843859 & 117766738 & 132780473 \\
\hline
\end{tabular}


This article is published by Taylor \& Francis in the Journal of Peasant Studies on 28 May 2012, available online: http://www.tandfonline.com/doi/abs/10.1080/03066150.2012.675574\#.VeCmAPmqqko . To cite this article: Visser, O., N. Mamonova and M.Spoor (2012) 'Oligarchs, megafarms and land reserves: understanding land grabbing in Russia', Journal of Peasant Studies 39:3-4, pp.899-931

transaction

\section{Total amount of land}

Total amount of land in Russia

$1709800000 \quad 1709800000 \quad 1709800000 \quad 1709800000$

Total amount of

agricultural land in

402300000

400000000

Russia

Land transacted as \% of

the total amount of land

in Russia

Source: Authors' compilation based on Rosreestr (2010).

Notes: Land transactions include buying, selling or leasing of all categories of land: agricultural land, settlement, industrial land, special protected land, forest, and reserved land. Therefore, we calculated land transacted as percentage of the total amount of land in Russia, which somewhat understates the share of land transacted. However, if we would consider the land in transaction as only agricultural land, we would arrive at nearly 30 percent of agricultural land being bought, sold or leased per year in Russia, which likely overstates the percentage transacted.

The origins of the companies that are interested in Russian land acquisitions are quite diverse. Roughly we can distinguish the Western companies investing primarily in the European part of Russia, and the Asian (most notably Chinese companies) in Siberia and the Far East ${ }^{9}$ of Russia (Visser and Spoor 2011b). Investors from the Middle East (in particular from the Gulf States) have only been searching for land in some of the former Soviet republics very recently and have not yet concluded major deals (Visser and Spoor 2011b). Until now Gulf States investors have focused more on Ukraine and Kazakhstan rather than Russia. When discussing the origin of investors it is important to realize that the identity of investors might be different, and more complex, than what it seems at a first glance. Various recent studies in Africa have shown that what appears to be foreign investment is in fact investment by representatives of the diaspora from the target country. Furthermore, Hall (2012) has shown that the widespread land acquisitions by South African investors across the African continent are often indirectly based on Chinese investments in South African companies that are funding these acquisitions. Part of what seems like foreign investment appears to consist of investment by Russian oligarchs (Visser and Spoor 2011a).

Finally, a note about the aim/orientation of foreign farmland acquisitions. Globally an important share of the large-scale farmland acquisitions is not (solely) for food or fodder but also for biofuel production, for instance in Brazil and large parts of Africa ${ }^{10}$. In Russia, the share of land acquisitions aimed at biofuels production is rather insignificant. Various factors

\footnotetext{
${ }^{9}$ The Russian Far East concerns the easternmost parts of Russia, between Lake Baikal in Eastern Siberia and the Pacific Ocean. In Russia, the region is usually referred to as just the 'Far East'.

${ }^{10}$ Disentangling the food, fodder and biofuel functions of agricultural production is sometimes difficult, as it consists in part of 'flex crops' which can be used for multiple purposes.
} 
seem to play a role here. Russia, which is itself a prime oil and gas exporter with low internal fuel prices, does not actively stimulate biofuel production as is done, for instance, in Brazil and the USA. This makes the Russian case special, although the mechanisms of land grabbing are often comparable. Foreign investors who want to produce biofuels for export (mainly to the nearby EU) prefer Ukraine, which has better port infrastructure and a government that is more interested in stimulating biofuel production and processing, being very oil-dependent on neighbouring

Russia $^{11}$.

\section{Motivations for large-scale land deals: finance and the political economy of the land rush in Russia}

The recent land rush in Russia has clear characteristics of a new frontier for investors. In the creation of this new frontier, global factors play a role (such as the financial crisis and the search for an inflation hedge) but domestic factors seem to be more decisive. Also domestic land acquisitions predominate over foreign ones.

After the slump of the 1990s, the Russian economy has shown impressive growth rates throughout most of the 2000s and demand for high quality food products, such as livestock products, is continuously rising. An important factor on the supply side is the large amount of capital in the hands of the Russian oligarchs, which after the appropriation of the energy and industry sectors are looking for new frontiers of development. Whereas in the 1990s they transferred their capital to tax havens in the West, with the economic recovery of the 2000s these oligarchs increasingly started investing their offshore capital again in Russia. By 2002, a senior economist of the Moscow Brokerage firm Aton Capital Group concluded, 'Russians are starting to trust Russia' and therefore 'money is coming back' (Starobin and Belton 2002).

The land rush can be seen as part of the larger 'hunt for the Next Big Thing', the new accumulation drive that started in the 2000 s with the privatisation of assets which were left in state ownership in the 1990s, such as railways, electricity and financial services (Starobin and Belton 2002). The Russian state plays an important role in enabling the boom in large-scale land acquisitions, in legal terms by adopting the 2002 land law allowing free sale of land and, even more important, by financial stimulation through mechanisms that lower taxes and increase subsidised loans.

The fact that the current boom in agriculture takes the form of large-scale land acquisitions with the predominance of huge agroholdings is often portrayed as an inevitable process or the most efficient mode of farming for Russia, by investors and authorities alike. While it is true that the Russian landscape and the crops cultivated allow for a high degree of mechanisation and economies of scale, there are also various diseconomies of scale associated with these large farm enterprises (Nikulin 2005, Visser 2006, 2008), such as those related to monitoring costs. Another justification for large-scale land acquisitions and mega-farming given by the major actors in Russia is that the rural population is not willing to take up independent farming, that small or medium private family farms are not a feasible form of production, or do not have the finances to expand and modernise production. 'Today only agro-industrial holdings can be profitable in farming, because it requires huge financial resources', stated

\footnotetext{
${ }^{11}$ In addition, a probably unexpected motivation for biofuel production is the following: in Ukraine biofuel production is used as a means to generate value from the Northern area around Chernobyl, which due to the radioactive contamination can no longer be used for food and/or fodder production.
} 
Zorigto Sakhanov, chairman of Agro-Invest Group, the subsidiary of Swedish Black Earth Farming (Bush 2008).

Indeed, the growth of private farms has been below expectations. However, it is important to stress that many of the farmers face obstacles which are not simple natural problems related to their size, but a direct problem of a political economy (and government policy) targeted at large-scale farming (Visser 2008). The lack of investment in extension services, as well as the large-scale nature of input and output channels, form obstacles for private farms (Visser 2008). Further, some regional authorities have set limitations on the minimum size of land deals, such as in Krasnodar Krai where there is a threshold of 300 ha for land deals, hindering the emergence and expansion of small and medium sized farms.

A very important factor that skews the agricultural boom towards large-scale farming is the financial system. There is an urgent lack of accessible finance/credit. Obtaining loans is virtually only possible through take-over and capitalisation by rich investors who have built up their capital in another sector, or via statesubsidised credit. Most commercial banks are more vehicles for the investment projects of oligarchs than accessible sources of credit. Interest rates are very high and agricultural land is mostly not accepted as collateral. Furthermore, banks are generally not much oriented toward agriculture.

From the early 2000s, the state has increased finance for the agricultural sector. A network of state-owned and operated banks for agribusiness was set up, but in some regions these bank branches were only established when agriculture had already virtually disappeared. Statesubsidised loans have been targeted predominantly towards large farm enterprises, and within this group, towards the largest and most successful ones. For instance, Uzun (2005) states that ' 1.4 percent of the largest corporate farms received 22.5 percent of all subsidies'. Also, the more indirect forms of subsidisation seem to stimulate mostly the largest LFEs ${ }^{12}$. Various requirements of the loans, such as the need for matching of resources and often brief repayment terms, skew the loans towards the largest farm enterprises. Due to the abovementioned problems, it is difficult to develop agriculture without investors that already gained capital in lucrative sectors outside agribusiness. Whereas in the 1990s, the few investors in agriculture and land were mostly coming from that sector (food processors, food wholesalers, or providers of inputs for farming), now they often do not have any existing link to the sector.

\subsection{Motivations for large-scale land acquisitions}

The precise motivations of outside investors/oligarchs to acquire land are not easy to discover since the whole process is highly non-transparent, not least for the villagers, who often know little more than that 'a rich investor from Moscow' obtained their land (D'Hamecourt 2010, p.13). However, it is clear, as we will elaborate below, that the current land rush cannot be explained sufficiently by economic incentives or rising food demand only, and we will proceed to disentangle a few other factors. With regard to the global food prices and land grab debate, several authors have argued that the idea of the growing global population and rising food demand as an explanation for rising food prices and subsequently the drive for land acquisitions is a mystification of reality (Jouko and Granberg 2011). This is clearly the case

\footnotetext{
${ }^{12}$ However, it should be noted that by the mid-2000s the national budget for the first time since the mid-1990s set aside a substantial amount of subsidies for household plots and private farms (Wegren 2007).
} 
for Russia. Except for the more obvious economic reasons for investment, such as increased demand for livestock products, and aspects of investment portfolio management (integration, differentiation and risk-spreading), there are several other motivations for investment. The following will be discussed: high subsidies, speculation, state pressure and state-business agreements, tax evasion and money laundering.

\subsubsection{High subsidies}

Acquiring land and investing in agriculture has been made attractive by the policy of the Russian government. Since the early 2000s the state has stimulated agriculture through a range of instruments such as a debt restructuring programme, the establishment of a statefinanced agricultural bank, subsidised crop insurance programmes, simplified and lowered taxes on agriculture, and subsidised loans for capital investment (Wegren 2007, p.517). Whereas in the 1990s subsidies for the agricultural sector were sharply curtailed, under Putin, from 2006 onwards, agriculture became one of the four priorities of the 'national project'. The government set ambitious goals for domestic food security, targeting first of all the livestock sector, which experienced the most dramatic decline during the 1990s. As a result, cheap, state-subsidised credit is available for investments in livestock and especially dairy production. Asked about the motivations of the investors he had worked with, a Dutch interim farm manager and consultant, Han van Riel, who has worked in several agroholdings in Russia, answered:

...it could be, normally you get 10 million from the state, with a guarantee by Putin. The interest rate is zero percent'. [...] Yes, there are enormous funds. Look, normally the interest rate is 15 to 16 percent. But then it is zero percent (Han van Riel, Interview, 16 November 2011, The Netherlands).

Western observers often hasten to characterise state intervention in Russia as a legacy of, or return to, the Soviet past, but it is more productive to see it as an example of the wider global tendency of various states to stimulate a boom in agriculture. Whereas in some countries the subsidies focus on biofuel/diesel and energy security (such as the biofuel (corn) subsidies in the US, or biodiesel policies in Germany), in Russia, as a major fossil energy exporter and a weak food (livestock) producer, the subsidies focus on livestock production.

\subsubsection{Speculation and land conversion}

Land brokers and representatives of agroholdings searching for investment widely mention the expected value appreciation of agricultural land in Russia. Also, part of the land is obtained in order to sell it off later with a large premium as land for construction sites (in a later section several such cases will be discussed):

I have, [...] tried to cultivate cabbage, on 20,000 ha, for a real estate agent. He wanted it in ownership, at least, the right of usage. But he had to cultivate it, otherwise he would not get it [...]. Just what I thought. At least 50 to 80 percent of his territory is now expansion area for construction for Moscow for the next 25 years. He knew that already by then. Thus, yes, for him it was just to have it, due to its location in Moscow [region]... (Han van Riel, Interview, 16 November 2011, The Netherlands). 
This article is published by Taylor \& Francis in the Journal of Peasant Studies on 28 May 2012, available online: http://www.tandfonline.com/doi/abs/10.1080/03066150.2012.675574\#.VeCmAPmqqko . To cite this article: Visser, 0 ., N. Mamonova and M.Spoor (2012) 'Oligarchs, megafarms and land reserves: understanding land grabbing in Russia', Journal of Peasant Studies 39:3-4, pp.899-931

\subsubsection{Pressure by the government}

Furthermore, many political and other, often hidden, motives seem to play a role, such as creating loyalty and political support among regional governors and a tacit agreement with the Kremlin, which seems to have promised not to investigate the dubious practices of the oligarchs in return for their investment in the countryside (Boldyrev 2001, p.21). Interviews with consultants in agriculture suggested that regional authorities made agreements with the largest oligarchs that the latter should invest in the cumbersome agricultural sector in return for earlier or forthcoming privileges such as tax breaks, cheap credit or other forms of state support (Visser 2008). Obviously it is difficult to find clear evidence for such influence, but anecdotal evidence suggests that this indeed played a role. The quoted Dutch interim farm manager confirmed this pressure: 'I think one of the motives is the choice you have: either you pay tax arrears or you start producing food' (Han van Riel, Interview, 16 November 2011, The Netherlands).

For instance, one investor, the director of a fur factory described by Kalugina and Fadeeva, started to invest in a near-bankrupt farm enterprise after multiple requests by the district authorities, with promises of state support and privileges for its development. The investor described the interaction: 'The district head insisted that I who come there [to invest]. He said "nobody except from you can revive this enterprise'. I tried several times to run away from it' (quoted in Kalugina and Fadeeva, 2009, p.165). A German investor even stated that 'the land was almost forced on us' (Winter 2012).

\subsubsection{Tax evasion and money laundering}

Furthermore, tax evasion, and probably money laundering, seems to play a role (Boldyrev 2001). Agriculture is a complex sector, with large fluctuations in production and profitability year to year, which allowed for extensive creative accounting already in the Soviet period (Visser and Kalb 2010). Furthermore, the tax on agricultural production is low to virtually zero.

\section{Abandoned land, dying villages and investment: discourse and reality}

Whereas the previous section looked into the motivations behind the land rush, this section will turn to a major topic in the legitimisation of these deals: the concept of 'abandoned', 'unused' or 'available' land.

\subsection{The discourse of abandoned land}

The idea of widely available abandoned land waiting to be (re)cultivated is very widespread among media and investors describing the Russian countryside:

You should take the car. Drive to the North, [further] across Belarus, and then towards the South, Smolensk, and in the direction of Moscow. Or even go further. [...] Then you will meet millions of hectares which are just abandoned. Nobody is living there anymore (Interview with Dutch consultant/farmer Han van Riel, 16 November 2011, The Netherlands). 
This article is published by Taylor \& Francis in the Journal of Peasant Studies on 28 May 2012, available online: http://www.tandfonline.com/doi/abs/10.1080/03066150.2012.675574\#.VeCmAPmqqko . To cite this article: Visser, O., N. Mamonova and M.Spoor (2012) 'Oligarchs, megafarms and land reserves: understanding land grabbing in Russia', Journal of Peasant Studies 39:3-4, pp.899-931

and:

Back then this tradition-rich region was on its knees. The giant state agricultural collectives of the Soviet era were all bankrupt; their ancient equipment was in disrepair, and their land stood largely fallow. Young people fled to urban areas, leaving behind aging parents, decrepit farm houses and weed-choked gardens. Today, however, the region has burst to life. The capitalist upheaval that years ago began sweeping through Russia's big cities and oil and gas fields has finally made its way to the country's rural heartland. Newly imported tractors and harvesters with the latest ground-positioning satellite systems navigate vast privatized estates, producing bumper crops of wheat, barley, rapeseed, sugar beets and corn. (Kandell 2009, 1)

The director of the largest German investor in Russian agriculture (Ekoniva) states: We change the attitude to land. In every farm we start restoring abandoned, neglected, often uncultivated lands and some points which were marked as fields on the map even appeared to be forest-belts in reality (Zaslavskaya 2010).

\subsection{Is a win-win situation possible?}

If anywhere, it would appear that a 'win-win' situation proposed by investors and for example studies such as World Bank (2010a) on land deals would be possible in Russia. A few features of agriculture in Russia suggest, at a first glance, that this is indeed the case. First, in general there is no food shortage or hunger. Russia is even a main exporter of grain (although importer of livestock products).

Second, much land is not cultivated. Indeed, rates of land that turned from agriculture into non-agriculture were very high in Russia in the 1990s, with this process already starting in the 1980s during the last decade of the Soviet Union (Ioffe and Nefedova 2004). Prishchepov et al. (forthcoming) show, based on detailed Landsat satellite data, that 52 percent of agricultural land in the North-Western Smolensk region was 'abandoned' between 1989 and 2000. Ioffe, Nefedova and Zaslavsky (2006) estimate that about 30 percent of Russia's rural settlements 'have either died out or are about to do so'. Ioffe and Nefedova (2004) suggest that as a rule farm enterprises are not profitable in areas where population density drops below 10 people per square kilometre. Low population density, an aging rural population, and out-migration of working-age people all confirm the image of abandoned land. Ioffe, Nefedova and Zaslavsky (2004, p.934) even speak about 'black holes' in the countryside. In some villages most of the titles to land were in the name of people who had disappeared or owners who had died. In one district, Shagaida (2005) found that nearly half of the land shares were owned by people who had $\operatorname{died}^{13}$.

Third, the population often appears willing to rent out or sell the land. A farm consultant for large-scale farms in Russia states:

Indeed many do sell their land. Some [of the rural population] do nothing with their land, which is just laying fallow. They don't get any revenue from it. And as I just said, if they hand it over to the large enterprise - let me put it that way - then they get some return

\footnotetext{
${ }^{13}$ In addition to an indication of aging in the countryside, it is also an indication of the difficulties of registering land for rural dwellers.
} 
from it. They earn something from it (Simon de Schutter, Interview, 13 January 2012, Holten, the Netherlands).

There is no widespread desire to become an independent farmer. In fact, in the 1990s, when some new independent family farmers emerged, a large share of the population was quite hostile to these efforts as they feared for the break-up of the LFEs and the loss of their lowpaid, but until then 'secure', jobs and the whole social infrastructure, pensions, etc., connected to it (Visser 2008). The majority of the working-age people (and a lot of people above pension age trying to supplement their low pensions) prefer to have a job at a LFE. Consequently, many of them are indeed happy if an investor approaches them to buy or rent the shares with the promise to lift up production and re-create employment. Quite a large part of the population is above working age and would physically be unable to work the land.

\subsection{A critique of the discourse of abandoned land}

Despite the arguments above, one should not jump to the conclusion that therefore land acquisitions in Russia cannot be but beneficial for rural dwellers next to the investor.

First, empty or uncultivated land is predominantly in the north (with poorer soils, and worse climatic circumstances) where hardly any investors are interested in obtaining land, with the exception of land near the large cities (Uzun 2011). In the well-endowed south, there is fallow land in the peripheral regions but here investors are also mostly not interested in obtaining land. A Dutch farmer/investor, who on a trip to Russia in search for agricultural land, met with a mayor showing him a potential investment site, stated in an interview:

...we said, ok, that is not worth investing in anymore. If we want to start with a big unit, than we like to build it near a big road. There we have good infrastructure... [...] we didn't want to build it in the village. We wanted to put it in the middle of the fields. That works most efficient (Farmer De Boer, Interview, 13 January 2012, The Netherlands) ${ }^{14}$.

Second, when land is not cultivated it does not mean that land is unused. Often villagers do use it in some ways and have (informal) entitlements to land for functions other than agricultural cultivation, involving such functions as grazing, hunting, bee keeping and mushroom or berry collection. It is important to note that in the Soviet era, a symbiosis existed between the collective farm and the household plots of the employees and other villagers (see Visser 2006). Households were mostly allowed to let their private livestock graze or bees forage at the fields of the collective farm. Further, the collective farm, as a rule, ploughed the household plots and provided free inputs such as manure or fodder for private livestock. Most of these entitlements were mutually agreed between farm management and employees, although employees and villagers also had one-sided claims on collective property, which were considered stealing by the farm management. The land reform and reorganisation of the farm enterprises in the 1990s did not take into account these existing property relations.

\footnotetext{
${ }^{14}$ The mayor did not agree with starting a new investment site further away from the village, and as a result the investor continued to search elsewhere. The investor could understand the position of the local authorities and mentioned their care for the rural inhabitants with some appreciation. The word 'mayor' is used here following the terminology of the interviewee.
} 
Research on property in other countries has shown that informal property rights are often overlooked during property reform, and it is not easy to do justice to the complex web of preexisting property rights when formalizing them (von Benda Beckmann 2003, von Benda Beckmann et al. 2006). While many of the farm directors continued part of these longstanding, informal entitlements after the land reform of the 1990s (Spoor and Visser 2004, Visser 2009), with the emergence of outside investors farm property is often fenced off, support to households is curtailed and guards are installed (Visser 2008, Nikulin 2010). Nikulin (2010) shows in his case study of a large investor in Perm region that while villagers quite easily sold their land shares as they did not cultivate the land, they often persistently opposed the new production technologies (industrial ploughing and chemical fertilisation) brought along by the investor, which disturbed the livelihood they had built on the 'abandoned' land. The investors stated:

Now we ...will increase the ploughing area up to 7 thousand, [...] Meanwhile, many people here have formed a certain life style, the life style of living in the forest. They go to the woods, they keep bees. When we arrive here with an active production cycle, to some extent we disrupt their social rhythm. Now they cannot already wander in the fields and ride as they please, because the fields are ours, and they are ploughed by us, [...]. Instead of their wild strawberries there is, let's say, our pea. We begin ploughing the young forest with which the fields are overgrown, but there are mushrooms there (Nikulin 2010, 26).

Third, even if land is uncultivated usually there is an owner. Although part of the population is prepared to sell or rent out their land, not all of them want to do so. Some would be able to work the land physically. Some of them sell the land because the institutional environment, described earlier, is such that they have difficulty getting finance or registering their land, and also sometimes there are regional limitations (minimal limits to the size of farms).

Fourth, the rural dwellers are often in unequal power relations vis-à-vis the investors and rarely get a good price for their land. Here the difficulties mentioned earlier, of registering land for rural dwellers, play an important role. Costs of registration hamper them in their opportunities to sell the land freely. Often, the costs of registration are prohibitive and investors buying the land take up these costs. Even when agroholdings 'freely' buy up the shares of the employees, as is often the case with LFEs, the management and employees often sell under pressure from the investor. In a survey among 200 farm employees who sold off their land shares to an agroholding, 156 answered that they did so under pressure of the holding group (Gerasin et al. 2003, p.176).

\section{Land accumulation strategies}

A major consequence of the share-based privatisation of land was that large farm enterprises (LFEs) retained control over former state-owned agricultural land because most land shareowners rented their share allotments back to the large farm in return for payment (incidentally, villagers rented out their land to private family farms but in many cases there was no other actor to rent the land to than the local farm enterprise). As a result, investors in search of land normally encounter large farms with integrated landholdings, but with actual ownership being very dispersed in the form of land shares. A relatively small amount of agricultural land concerns land shares concentrated in the hands of one, or a few, owners. Normally these are farm managers or outsiders who managed to obtain shares from the rural 
population. Finally, as mentioned earlier, a minority of agricultural land is still held by the state (often regional authorities or municipalities).

There are several strategies to acquire land in Russia. Land can be leased, or it can be bought in various direct and indirect ways. Buying up (or leasing) land from a large number of land shareholders takes quite some time. It was shown earlier that the registration procedure leads to high transaction costs. Sometimes investors try to avoid the time-consuming and bureaucratic procedures of acquiring land, in order to grab land at a very low $\operatorname{cost}^{15}$. Frequently, the strategies of land acquisition within the framework of the law are combined with or substituted by means that contradict the national laws or obey the letter of the law but not the spirit, using loopholes of Russian legislation to legalise unfair land acquisition ${ }^{16}$. Thus, one could discern a continuum of land acquisition strategies, running from acquisitions within the framework of the law, strategies at the fringe of the law (including misinformation, deceit and pressure), and finally outright fraud and dispossession. Due to limitations of space, the discussion below will cover strategies at the two opposites of the spectrum and largely leave aside the in-between category.

\subsection{Land accumulation strategies within the framework of the legal system}

The first way of obtaining land is leasing or buying land from (dispersed) land shareholders. Lease was already possible before the 2002 land law on land transactions. Buying and selling of agricultural land by individuals is minor compared to leasing land shares from shareowners (or the state). According to the research of Lerman and Shagaida (2007) in corporate and peasant farms, the share of leased land is on average 60 percent of the total area of agricultural land used. In corporate farms, three-quarters of the leased land is in the form of land shares and only one-quarter is leased as land plots.

Currently, much of the land acquired by agroholdings is rented, but there seems to be a growing tendency to buy land, which is of course partly due to the law of 2002. Based on our web research and interviews, we can conclude, not surprisingly, that foreign investors prefer buying to leasing. In our interview with Gustav Wetterling of Agro-Invest Group, he said:

We have significant costs related to getting rid of all the weeds, all the trees... So that's why we want ownership. So we know that we have it for a long period, so we will get this money paid back. There is a significant investment in the beginning... (Interview 23 September 2010, Moscow).

Many agroholdings do not disclose information about land in use and ownership, but the official web pages of the main ones which do so suggest that the abovementioned statement by the representative of Black Earth Farming is indicative of a wider trend.

This company buys land rights directly from every individual shareholder, making an agreement with rural dwellers to register the land unit in their name and on their behalf and then buying this land according to a sale-purchase agreement. When Black Earth Farming

\footnotetext{
${ }^{15}$ It should be noted that these strategies are mainly used by domestic agroholdings or ones that are offshore investment funds of Russian oligarchs.

${ }^{16}$ Also some deals which are within the framework of the law, such as a deal involving a farm director selling his land shares to an outsider, may have been preceded by a fraud in obtaining these shares from the rural population but with the legal period for filing a complaint on the early fraud expired.
} 
began land acquisitions in 2004, it paid 90 Euros per ha (Kandell 2009). According to the director, the shareholders were happy to sell their rights as they were not able to register the lands themselves due to bureaucratic obstacles and the costs of registration, which can be too high for poor villagers; hence, their land did not provide them with any income. Gustav Wetterling stated that 'during the last two years we got one offer per week to buy a land plot. There is no shortage of land for sale in Russia right now' (Interview 23 September 2010, Moscow).

The same mechanism was used by Agro-Invest Brinky BV. The CEO of this Dutch company, Willeke van den Brink, stated that it was difficult to acquire the shares of former collective employees. 'It was problematic not only to agree on the (conditions of the) sale, but even to find all these people: someone died, someone had left, et cetera' (Luchev 2009). Acquiring shares for a controlling stake in the hands of Agro-Invest Brinky took close to one year. Dealing with large numbers of shareholders is a common downside for investors building up an agroholding in this way. The UK company Heartland Farms Ltd, owner of 18,500 ha in 2009, concluded contracts with around 1500 land owners (BTA Analitika 2008, p.15).

A way to obtain large amounts of land in one go without numerous negotiations with individual land shareholders is, first, to buy a whole farm enterprise (in which land shares were already accumulated by the farm management). Buying land in this way is in some cases not done completely legally (see next sub-section). The villagershareholders do not always want to invest their shares in the companies. Investors used tricks, and some started preparing the documents of the enterprise and placing their managers in the farm staff several years before they announced their wish to acquire the farm ${ }^{17}$.

Second, a minor, but increasing, percentage of land has been accumulated by companies and is offered for purchase. For instance, Gazprom, which ended up with half a million ha of land, is selling off much of this land. Also some agroholdings which grew rapidly sell off some of their land due to financial problems or to cluster their land in a few regions. In these two variants, a (foreign) investor faces fewer transaction costs in obtaining land, but of course it has to deal with all the other organisational issues of starting up a new farm enterprise, which can be quite a laborious process in Russia.

With the emergence of increasing numbers of domestic agroholdings in the past few years, there are foreign and domestic investors that have taken equity (whether a minority or majority share) in these entities. Several large domestic agroholdings in Russia and Ukraine are even quoted at stock exchanges in Western Europe and others recently have announced plans to do so. Also some Western agribusinesses operating in Ukraine and Russia are quoted on stock exchanges, such as the French farming group AgroGeneration. Although this process of share emissions only started after the mid-2000s, currently Russia and Ukraine already have more agroholdings at the stock exchange than do the large agricultural powers of Latin America, Brazil and Argentina (World Bank 2010a). In this sense, Russia, which was still a socialist country dominated by state and collective farms two decades ago, is now at the 'forefront' of financialisation and large-scale global commodification of agriculture and land. An expert with Renaissance Capital stated that Russian agriculture will increasingly be

\footnotetext{
17 Based on interview with Tamara Semenova, vice-president of the peasant movement Krestyanskiy Front, discussing the case of the farm enterprise Matveyevskoye. Interview was conducted 29 September 2010 in Moscow, Russia.
} 
This article is published by Taylor \& Francis in the Journal of Peasant Studies on 28 May 2012, available online: http://www.tandfonline.com/doi/abs/10.1080/03066150.2012.675574\#.VeCmAPmqqko . To cite this article: Visser, 0 ., N. Mamonova and M.Spoor (2012) 'Oligarchs, megafarms and land reserves: understanding land grabbing in Russia', Journal of Peasant Studies 39:3-4, pp.899-931

dominated by agricompanies with capitalisation of over half a billion dollars (Vasilyeva 2008, p.2).

In February 2011, US-based PepsiCo, the second largest beverage and food company in the world, obtained a majority share in OJSC Wimm-Bill-Dann, the largest dairy agroholding in Russia. Wimm-Bill-Dann owns 37 food factories, many dairies around Moscow and elsewhere in Russia and even in other countries of the former Soviet Union, as well as port infrastructure. It also controls 40 large farm enterprises, with 20,000 ha in ownership and 250,000 ha in leasehold. The legal obstacle concerning foreign land ownership has been solved by transferring the land bank formally to the owners-founders, who had the controlling share before PepsiCo came in. One of the largest agroholdings in Russia, Cherkizovo Group OJSC, which holds numerous pig farms and fodder producing farms, is now predominantly owned by US investors, namely JP Morgan Chase Bank and MB Capital Partners. Also in the Far East of Russia, agroholdings are taken over by foreign investors (Visser and Spoor 2011b).

\subsection{Land accumulation outside the legal system}

There is increasing evidence of illegal land deals in Russia, in a land market which is generally far from transparent. According to official statistics, the number of land disputes in the first half of 2008 compared to the first half of 2007 increased by 63 percent for the whole system of arbitration courts of the Russian Federation ${ }^{18}$. An analysis of crimes associated with illegal registration of land transactions also indicates growing abuses associated with the misappropriation and illegal registration of land transactions (Moskalkova 2011). The 'leader' in terms of criminal investigations is the Moscow region, due to its advantageous location close to the capital and due to the high land prices, which reach 1000-1500 USD per square metre as a consequence of demand for land to build dachas ${ }^{19}$ (fieldwork of Spoor and Visser 29/10/2011). In 2011, the Governor of Moscow region said that 'almost of all of them [the investors who buy large plots of land] have problems with documents about the land rights' (Moskalkova 2011). Tamara Semenova (Krestyanskiy Front) stated:

[S]ince the moment that, in 2002, the state law about the turnover of agricultural lands came into effect and land became a commodity, illegal court practices have become popular in the Moscow region. Before 2002 the land rights were given to peasants, after 2002 - the other way around' (Interview, 29 September 2010, Moscow).

In almost every district of Moscow region, there are land conflicts between peasants and the new owners of the land, according to the Krestyanskiy Front. Moreover, the illegal land deals do not only happen in the Moscow region, but also in the wellendowed regions of south Russia (for instance Krasnodar) and in various other regions (Visser and Mamonova 2011), where land acquisitions focus less on conversion into construction sites than in Moscow region. However, due to the fact that these regions are covered less by the mass media, the situation there is less well known.

\footnotetext{
${ }^{18}$ Report of Arbitration Court of Bashkortostan Republic 2008.

${ }^{19}$ Dacha is a Russian word for seasonal or year-round second homes often located in the exurbs of the country. It is estimated that about 50 percent of Russian families living in large cities have dachas.
} 
According to Tamara Semenova, 'invaders' usually pretend to be investors, offering to invest in the development of agricultural enterprises by buying shares. If the peasants refuse to sell their shares to these investors, then various illegal schemes are used to achieve the goal. Manipulations with land units through forgery of farm enterprise documents on land ownership is the most common illegal method of weaning the land from the peasants, because technically and time-wise it is most simple to realize. For example, employees of former state farm Zaoksky in the Serpukhov district of Moscow region have lost their land as a result of the enterprise bankruptcy. As a result of bankruptcy proceedings, more than six thousand ha of land were purchased for only 10.8 million roubles (approximately 270,000 euros) by Center-Capital CJSC. As a result, over two thousand people lost their legal right to the land shares.

Another criminal case has happened with CJSC Matveyevskoye in the Odintsovo district. This case can illustrate an important mechanism through which land grabbers acquire land. First there was the falsification of a meeting of shareholders, at which they ostensibly gave their shares to the capital of the enterprise. This already took place in the 1990s. There was also a case between the two main shareholders of the farm. Supposedly, they were going to share their land shares. This court case was specially fabricated to get control over the land shares. During this court case, Matveyevskoye acted as a third party. Matveyevskoye came with a counterclaim to recognize the rights to the entire land mass for Matveyevskoye. Finally, the court recognized the property rights of Matveyevskoye on the land shares of a common area of 712.4 ha of land of agricultural value (land value of more than 600 million roubles - approximately 15 million euros). Shareholders came to know about this court case, which was carried out in another region, only three years later when the statute of limitations had passed. In that period the former CEO of Matveyevskoye N. Dubrovsky and the next CEO V. Bobynin were assassinated, murder cases that remained unresolved.

For six years, the shareholders of Matveyevskoye have been seeking the recovery of their land shares. However, the prosecutors and investigative bodies, one after another, refused to initiate criminal proceedings. Currently, Matveyevskoye is owned by a company registered in Britain, Millhouse Capital UK Ltd, which manages the capital of the famous oligarch Roman Abramovich and the company Inteko (headed by Elena Baturina - wife of Moscow ex-Mayor Yuri Luzhkov). There seem to be no real plans to develop agriculture as had been promised. The lands are used to build VIP country houses and business centres. On 1 November 2008, appealing to the article 159 Part 4 of the Criminal Code ('fraud, committed by a group of persons on a large scale') the criminal case No. 152983 was initiated against the 'raiders' of Matveyevskoye. However, a few months later the case was dismissed at the request of the Moscow region Prosecutor's Office. Currently the victims are appealing to higher authorities for help.

\subsection{Countering illegal land acquisitions}

In a few cases, mobilisation by dispossessed rural dwellers who also pursued court cases resulted in some effect, but only after very long legal procedures (often involving multiple court cases at different levels). Former employees of a poultry farm in Krasnogorsk, Moscow region, were in a similar situation to Matveyevskoye above. The farm was acquired after the bankruptcy of the Agricultural Land Corporation Znak, co-owned by oligarch Nikolai Tsvetkov. Since 2001, people have been trying to restore their rights, but had not succeeded. 
However, in the middle of March 2010, the equity holders were paid 190 thousand roubles approximately 4,750 euros - (per share of $0.39 \mathrm{ha}$ ), to make them withdraw their complaints. The following successful case gives more insight into the enormous efforts and kind of strategies that are required by rural dwellers to achieve some form of justice.

'It is impossible to fight land grabbing with classical legal instruments alone', says Tamara Semenova of Krestyanskiy Front (Interview, 29 September 2010, Moscow). According to her, the courts in Russia, especially those that deal with land issues, are bought by raiders. The rural social movement, which was founded by dispossessed shareholders of a Moscow farm, is the most active among the recently emerging rural movements in Russia (Visser 2010, Visser and Mamonova 2011). It started by organizing public events (pickets) in Moscow city in order to draw the attention of federal authorities to this issue. It did not work particularly well. The state did not respond to their repeated appeals to address the large-scale dispossession of land held by rural dwellers. Recently the movement has developed another strategy. The movement decided to seek a solution on a case-by-case basis, trying to mobilize those rural dwellers directly involved and targeting the companies and authorities related to each case. Tamara herself was a leader of the movement of shareholders (600 people) of CJSC Agrocomplex Gorky-2 in reaction to an illegal action of acquiring land shares from shareholders without any compensation. For two years, the group of deprived shareholders has almost never left the Rublyovo-Uspenskoe highway where the management office of Agrocomplex Gorki-2 is situated.

We had been standing for two years three days a week from 8 a.m. to 5 p.m. with placards along Rublevka ${ }^{20}$. Well, because it was Rublyovo-Uspenskoe highway, many officials and government members use that road every day and they had been asking our raiders: 'When will you pay, when will these protesters leave the road?' It was the sore point that we found. Courts didn't work for us, of course. In courts we lost every case. Totally absurd decisions were made by courts, even sometimes hard to believe: is that a circus or a court? (Interview, 29 September 2010, Moscow).

In total the fight against the Agrocomplex Gorki-2 took five-and-a-half years. According to the Krestyanskiy Front leadership they experienced threats and violence and were offered bribes in attempts to stop their efforts (Tamara Semenova, Interview, 29 September 2010, Moscow). But the activists continued their activities to get compensation. Finally in 2008 the shareholders got financial compensation for their lands.

The previous two cases led to compensation being paid, but restitution of the dispossessed land was not achieved. In Moscow, we have found only one court case of illegal land acquisition that has led to land being returned to the former, rightful owners. One of the main landlords of the Moscow region, JSC Vash Finansoviy Popechitel, has more than 63,000 ha in Ruza district in the Moscow region. The Chairman of the Board of Directors Vasily Boyko is currently under home confinement. He is charged under the articles of 'large-scale crime' and 'legalisation of monetary funds or other property acquired as a result of crime'. Vasily Boyko used a standard way to assemble the lands: buying up the collective farm land units. $\mathrm{He}$ acquired nine of eleven farms in Ruza district with a plan to develop a real estate project called 'Ruza Switzerland'. The resort should occupy 40 ha in Ruza district. The project included a country hotel with a golf club, equestrian parks and spas, sports facilities and yacht

\footnotetext{
${ }^{20}$ The name 'Rublevka' is derived from the name of Rublyovo-Uspenskoe highway. It is an unofficial name of a prestigious residential area west of Moscow, Russia.
} 
clubs, a ski resort, a mini-airport for sports and business aviation, helicopter pads, a safari park and elite cottage villages.

However, due to the activities of resentful peasants and the end of the support from local authorities, the project had to be postponed. Nevertheless, it is questionable whether peasant mobilisation in the form of a court case and demonstrations alone could have achieved this result. Some authors say that a number of the deprived peasants had private connections with bodies of internal affairs and that due to these connections their request was met (Kozyrev and Abakumova 2008). Others argue that Boyko lost the support of the local authorities and that is why he lost the court case (Solomatina 2007). Meanwhile the CEO of Vash Finansovy Popechitel, Maria Loboda, expressed her point of view that the arrest of Boyko is linked to the struggle for control over the land in the Ruza district. 'The purpose of this attack is to take away our business by competitors, and law agencies are used as a tool to achieve this goal,' she said in an interview to Rambler Media Group (Rambler 2007). According to Boyko's lawyers, the criminal case was initiated by organisations that are interested in obtaining contracts for the construction of the Central Ring Road and have close contacts with the government of the Moscow region. In this last version, which might be compatible with the earlier explanations, the restitution of land is not a sign of the impartial functioning of the rule of law, but rather the result of a power struggle within the arena of the business and political elites that offered a rare window of opportunity for the rural dwellers, an example of 'divided elites', one of the political opportunity structures for social movements as described by Tarrow (1998). Therefore, it is important to take a look at the role of the state.

\section{The state: policies regarding foreign land investment and land grabbing}

\subsection{Attracting foreign investment}

Agrarian policy of Russia in the Putin/Medvedev era (the 2000s and beyond) has become characterized by what has been called 'economic nationalism' (Wegren 2009a, b); with more focus on food security, increased customs duties (formal, or informal through quality controls), and increased use of food policy as a political tool in international relations ${ }^{21}$. Nevertheless, the authorities seem to be convinced that modernisation and production increases could be enhanced with foreign investment. As a consequence, over the past few years the Russian government is actively encouraging this.

By Russian law, foreign persons and companies are not allowed to own land. However, the legal loophole to avoid this, by establishing a majority or fully owned daughter company in Russia, is not at all frowned upon by state officials. In fact, this loophole is actively promoted. During a seminar on investing in Russian and Ukrainian agriculture, a Dutch farmer, operating in Russia, complained about the fact that a foreigner cannot own land. The Russian vice-minister of Agriculture responded that it is no problem, as a foreigner 'you just open a subsidiary in Russia, and buy as much land as you want' ${ }^{22}$. On the regional and local level the

\footnotetext{
${ }^{21}$ Examples of food policy as a political weapon in Russian international relations have been the wine ban for Georgia and the 'milk war' with Belarus (Wegren 2009a, b, 2010).

${ }^{22}$ This is based on observations by Visser during a seminar on investment opportunities in the Agribusiness of Russia and Ukraine, held in Wassenaar, The Netherlands, November 2010.
} 
This article is published by Taylor \& Francis in the Journal of Peasant Studies on 28 May 2012, available online: http://www.tandfonline.com/doi/abs/10.1080/03066150.2012.675574\#.VeCmAPmqqko . To cite this article: Visser, 0 ., N. Mamonova and M.Spoor (2012) 'Oligarchs, megafarms and land reserves: understanding land grabbing in Russia', Journal of Peasant Studies 39:3-4, pp.899-931

stance of the authorities differs, depending to a large extent on the governor in charge (Zimin 2010), but most authorities encourage both domestic and foreign investment in agriculture ${ }^{23}$.

\subsection{Policies to address illegal land grabbing}

There are some attempts by the Russian federal state to prevent illegal land grabbing, at least in discourse. High-ranking Russian officials have recently condemned illegal land grabbing and announced measures to prevent it. Former Minister of Agriculture Aleksei Gordeev criticized urban 'raiders' and warned of 'wars' over rural land. As land 'raiding' became more frequent Gordeev advocated greater government regulation of land relations in order to protect the property rights of land shareholders (Wegren 2009b). In 2011, president Medvedev condemned land 'raiders' in a speech and proposed laws to limit conversion of agricultural land into construction land as a main tool to deal with the issue. Overall, there is very little indication that the regulations by the state are guided by a concern for the dispossession of land held by the rural population. Farmer movements fighting in defense of the rural dwellers' land rights have not been allowed a single meeting with federal government officials. In discussions on land governance between officials and academics from FSU countries within the framework of meetings on the voluntary guidelines for land grabbing by FAO in Moscow (November 2010), of all the officials, Russian officials were least inclined to introduce policies to allow free or transparent access to land registration for the population ${ }^{24}$.

Instead, current policies (and proposed new regulations) are largely oriented at keeping intact (and furthering) the concentration of land and the dominance of agroholdings, with more power for government land governance bodies (see also Wegren 2009a, b). In 2010 the Ministry of Economic Development and Trade began working on amendments to the Land Code, although there is no indication as to when these might be considered by the Duma. Draft legislation suggested by the Ministry of Agriculture will: (1) give right of first refusal to large farms to lease reregistered land; (2) give preference to municipal and regional governments to convert unclaimed, unwanted, and abandoned land to state property; (3) increase fines and/or land taxes for land that is used inappropriately or is not used for its intended purpose; (4) create a unified system of state monitoring of agricultural land.

At the moment, two main ways of controlling the land market are implemented. First, conversion of agricultural land into non-agricultural is becoming more regulated. As Anton Mitrofanov, director of the real estate agency Housing Strategy, stated, 'it was relatively easy, in negotiation with the municipality and with limited expenses, to convert agricultural land into another category, for instance for the construction of dacha (summer house) complexes' (BFM 2011, p.3). Beginning in 2011 it became more complicated as Federal Law (2010) N 435-FZ 'On Amendments to Certain Legislative Acts of the Russian Federation with regard to improvement of agricultural lands' entered into force, which contained additional requirements to a transaction of the land is converted from agricultural to construction purposes, making such a conversion more difficult. In the Moscow region, where illegal land deals are particularly widespread, to prevent widespread conversion of land for agricultural

\footnotetext{
${ }^{23}$ For instance, Visser had various conversations with Dutch businessmen who told him that they were offered agricultural land to start a farm by various regional authorities, on visits for business in other sectors.

${ }^{24}$ Observations by Visser at the FAO Voluntary Guidelines regional consultation for the CIS in Moscow.
} 
purposes to construction purposes the Federal Law No. 172-FZ 'On the transfer of land or land plots from one category to another' (2004) has been further elaborated. In the near future there will be annual quotas on the sale of land to prevent the sale of agricultural enterprises (to agroholdings). However, there is a danger that such measures will only add to further bureaucracy and corruption, without substantially reducing illegal conversions.

Second, regulations combating ineffective use of agricultural land have been introduced, and are more often enforced. Authorities can penalize owners for 'ineffective use' of agricultural land by penalties and even dispossession by the state of agricultural land that is not used for at least three years ${ }^{25}$. In 2009, several regions started to enforce the first part of this law. In Leningrad region, the authorities checked 170,000 ha, of which 10,500 ha were not properly used, thus total penalties for these land plots amounted to over half a million roubles (40 roubles was about one euro) (BFM 2011, p.2). Unfortunately, this enforcement can also be used to the detriment of land right holders who do not have the funds to 'properly use' their allocated land, and could therefore be dispossessed by law.

An important question therefore arises: namely, to what extent will these new laws and state policies of closer monitoring of land use (and penalizing or even dispossessing land in case of misuse) lead to constraints on illegal land acquisitions? Or will they facilitate dispossession and further land grabbing? First of all, the attempt to address the downside of land grabbing through handing more power to the state encounters the problem that the local authorities are strongly in favour of large-scale land acquisitions and are often part and parcel of the problem. It seems that land acquisitions are not possible without 'friendship' with, or at least ignorance by, the government. According to Tamara Semenova (Krestyanskiy Front):

[W] hen the raiders came and started buying land, they came not just off the street. It was by prior arrangement with the regional and district authorities. Who would let the strangers do this business in the Moscow region!? Well, we suppose they got the possibility to do this business for 'otkati'26 (Interview 29 September 2010, Moscow).

If authorities were willing to address the problem, what are their chances of succeeding? As mentioned earlier, authorities have conducted legal procedures to withdraw land that is not used for over three years from its owners. However, in practice it is not easy for authorities to succeed. In interviews with authorities in Moscow region, it was stated that it is very difficult for the state to win such cases, and the interviewees did not know of any example in the region where land was actually taken by the state. Sources from elsewhere in Russia confirm these statements (BFM 2011, p.2). Due to breaches of the legal procedures, the state loses these disputes (BFM 2011) in court cases with rich investors employing highly skilled lawyers.

Moreover, owners of agricultural land with speculative aims go to great lengths to circumvent above-mentioned laws. Some landowners are even building (partly) virtual agroholdings to accumulate low-priced agricultural land for other purposes ${ }^{27}$. Vasily Boyko of JSC Vash

\footnotetext{
25 According to article 284 of the Federal Law N 136-FZ 'Land Code; see: www.souzsad.ru/index.php/g1/39sgt/60-2011-01-26-19-51-51 of Russian Federation' (2001).

${ }^{26}$ Otkati (in English, kickbacks) - a kind of bribe (money or gift) to authorities.

${ }^{27}$ For more on the Soviet and post-Soviet mechanisms leading to 'virtual production' see Visser and Kalb (2010) and Kalb and Visser (forthcoming), and see Lindner (2008, 133-139) for a discussion of virtual accounting within agriculture.
} 
Finansoviy Popechitel has created the 'agricultural' holding Ruzskoe Moloko (Milk from Ruza), which sells packaged milk. However, the pastures are empty as livestock is sorely lacking. It appears that the company buys milk from farmers in neighbouring areas, which it (re)packages to sell under its own brand. Another example is oligarch Nikolai Tsvetkov's agricultural company Znak, which pretends to be a poultry farming agroholding. The bulk of the eggs the company 'produces' it actually buys from a poultry farm in another region and subsequently resells under its own brand.

Thus the law enabling confiscation of ineffectively used land so far does not pose a major obstacle for rich land owners, who can hire expensive lawyers and devise creative business strategies to prevent dispossession. At the same time, the law may form a threat for the rural population with their small land shares' land plots. Small-scale landowners who are temporarily unable to cultivate their land may easily lose their land as they are not able to hire lawyers to dispute confiscation of their land by the state. The situation of a school director in a village in Moscow region gives an indication of the uncertainty among the rural population due to this law. The director was close to his pension, but had no time to work the land currently. He was afraid that the state would take this land, and therefore he considered hiring someone to plough the land, to prove that he was cultivating the land ${ }^{28}$. Proposals in the Russian parliament (which to date have not been accepted) to have the state confiscate all land shares not yet registered (Wegren 2009a, 2011) would primarily lead to dispossession of rural dwellers, instead of limiting dubious land acquisitions by outsiders.

\section{Conclusions}

This research paper has analysed the post-Soviet land reform, the emergence of domestic and foreign investors, their types and the forms of land acquisitions, and the role of the state in the emerging land grabs. Russia (and the former Soviet Union in general) is largely overlooked in the land grab debate, although the process of land grabbing is occurring there at a great pace. Russia is a special case in the global land grab debate. It has vast amounts of land reserves and therefore is attractive to domestic and foreign investors. Russian companies, in particular in the energy and mineral resources sector, are very active in land acquisitions. Interestingly enough, these land deals are not for biofuels production as is the case in other parts of the world, since Russia is blessed with ample energy resources and low domestic energy prices as a consequence. Land has a speculative value and is meant for food production, urbanisation (construction land) and building dachas ('dachatisation').

Russia does not fit in the mainstream division of 'land grabbing countries' (oil-rich, and highly populated) versus 'target countries' (poor and land abundant). Russia is both an oilrich country and at the same time one of the most land abundant countries. Also, the case of Russia confirms recent critiques of the idea that land grabbing is predominantly carried out by foreigners. In addition, Russia does not conformably fit into the two main drivers of land grabs distinguished so far: food security (by governments) or commercial motives (by companies). In fact, in Russia the government plays an important role in stimulating largescale investments (despite some occasional rhetoric to the contrary), but not only with the (primary) aim of food security (at least not in the crop sector), but also with the aim of using

\footnotetext{
${ }^{28}$ Interview with school director, Moscow region, 14 February 2011.
} 
food export as a political tool in international relations (cf. Visser and Spoor 2011a, Wegren 2009a, b).

Although high levels of corruption and government intervention are a major drawback of Russia in terms of risk for investors, there are also a range of features of Russia that are likely to further raise the interest of domestic and foreign investors in large-scale land acquisitions. The huge size of landholdings and farm enterprises, and related infrastructure, is attractive for investors. Increasingly, land is available not only as large-scale land plots jointly owned in the form of hundreds of individual land shares, but also as ownership concentrated in the hands of farm directors, agroholdings or land brokers, although often not in accordance with Russian legislation. Also, foreign investors can take equity in large agroholdings registered on the stock exchange (Visser and Spoor 2011b). Despite the very recent emergence of Russia as an agricultural producer and major grain exporter, together with Ukraine, it already has more agricultural enterprises listed at stock exchanges than the established agricultural powerhouses Brazil and Argentina together. An increasingly high degree of 'financialisation' of the agribusiness sector in Russian is observed, which furthermore facilitates large-scale land acquisitions or land grabs by global investors.

The important question is whether this investment will be for the better or worse. On the positive side, the agricultural sector might receive an additional boost when investors introduce new technology to Russian farm enterprises. Foreign agricultural companies might set up new business standards in the agriculture sector in Russia. Gustav Wetterling of AgroInvest Group said that he 'doesn't think that it would be possible without foreign investments, without foreign companies that operate on Russian agricultural market, to achieve these results in agribusiness' (Interview, 23 September 2010, Moscow). Although a foreign company like this one, controlling 330,000 ha, has an important impact at a district or regional level, on a countrywide scale the predominance of foreign investors is restricted to some sub-sectors, such as poultry.

On the negative side, with growing numbers of domestic and foreign investors interested in agriculture, land dispossession and conflicts over land have risen as many (predominantly domestic) investors turned to illegal ways of acquiring land. While in Russia the 1990s represented the decade of struggle over property in industry and energy, in the first decade of the new millennium (2000-2010) attention for agriculture gradually increased, and the second decade (2010-2020) increasingly looks like the decade of struggle over land. Indeed, as Barnes (2006) pointed out in the quotation at the Section 4 of this paper, in the 1990s the property changes in agriculture still seemed underwhelming. Few investors from outside agribusiness (mainly domestic processors and among the foreign investors, former food importers to the SU) acquired land at that time. However, our research suggests that in quite a number of the illegal land grabs, farm directors, sometimes in cooperation with outsiders, already in the late 1990s and early 2000s paved the way for the land grabbing that became possible after the 2002 land code. In various cases, already in the 1990s meetings of shareholders and other documents were falsified to transfer land shares of the shareholders illegally to the charter capital of the farm enterprise (de facto to the farm director) ${ }^{29}$. Farm managers who forged documents in the 1990s cashed in on these early moves in the 2000s

\footnotetext{
${ }^{29}$ Whereas in Moscow region farm directors often did so with the perspective of selling it on to outsiders, in most other regions in the 1990s rising land prices were not (yet) anticipated and control over the LFE seemed to be the main motivation.
} 
when they could sell the land for huge profits, while rural dwellers were left landless without compensation. In summary, there is a wide range of strategies that are being used by investors and oligarchs to get land, from within the existing Russian legislative framework, to outright use of pressure, violence and fraud.

It is likely that land acquisitions will proceed at a great pace in Russia. There is little indication that the latest laws and the increased enforcement of laws limiting land conversion and 'ineffective use' of land will seriously contribute to constraining semi-legal and illegal land acquisitions. In fact, they might even contribute to the reverse - namely, increased dispossession of land of rural dwellers, as in the discussion on legalisation by Peluso and Lund (2011, p.674-675). They argue that rule of law often legalizes and legitimates the dispossession of the powerless. Governments and large corporations frequently 'operate with virtual impunity, while weaker actor may see rights whittled away' in the name of formalisation (Peluso and Lund 2011, p.675). In the Russian case there is an urgent need for improvement of the impartiality of courts, and the improvement of governance by authorities (in particular the transparency of deals between authorities and large-scale agroholdings). Without these measures and without stronger rural social movements defending the rights of the rural population, regulations and laws most likely will not reduce the risk of further land grabbing and dispossession.

The post-Soviet land reforms actually set the stage for the land grabbing that is taking place now, at least de facto, in the way they were implemented. Land basically remained under control of the large farms during the reform period of the 1990s, despite the rhetoric of equal distribution of land shares. Also, part of the farm management together with the help of outsiders already changed legal documents to allow for quick accumulation of land shares, once the land code was introduced.

After the approval of the land code in 2002, and with the rising profitability of agriculture, the large farm enterprises (and the agroholdings) are also acquiring de jure control over land, as they increasingly take over land through legal and illegal practices. However, de facto control of land by the LFEs should predominantly be understood as effective control vis-à-vis the rural population, whereas in relation to the state, their control remains insecure and depends on cultivating good ties with authorities. With recently introduced and proposed legislation giving the state more power over land, insecurity of land for rural dwellers, but also for LFEs, tends to increase. Only the largest agroholdings have such a financial power that the powerbalance between them and the state remains in favour of the agroholdings.

While it is shown that Russia is particular because it has huge land reserves, and therefore there would be a case to be made that 'win-win' land deals are possible, this availability of (unused) land thesis is undermined by the fact that much of the land reserve is available in areas that are not attractive for investors, and that where there is fertile land in better endowed regions, the very unequal power relations between investors and rural dwellers, and the weak legal framework (and enforcement of the law), leads often to unfair deals, dispossession and no or low compensation. In that sense Russia should be considered as a 'normal' case in the global land grab debate. 
This article is published by Taylor \& Francis in the Journal of Peasant Studies on 28 May 2012, available online: http://www.tandfonline.com/doi/abs/10.1080/03066150.2012.675574\#.VeCmAPmqqko . To cite this article: Visser, 0 ., N. Mamonova and M.Spoor (2012) 'Oligarchs, megafarms and land reserves: understanding land grabbing in Russia', Journal of Peasant Studies 39:3-4, pp.899-931

\section{References:}

Barnes, A. 2006. Owning Russia. The struggle over factories, farms and power. Ithaca, London: Cornell University Press.

BEFL. 2010. Russian market in agricultural land. PowerPoint presentation by Vladislav Novoselov, Director of BEFL, presented at the conference for agricultural producers and suppliers of agricultural inputs and services, Radisson SAS Slavyanskaya, 26 January,

Moscow.

BFM. 2011. Direktor zavoda v Posmoskov' e obvinen v makhinatsiyakh s zemlei [Factory director in Moscow region guilty of illegal land acquisition]. Available from: www.bfm.ru/ realty/2011/07/01/direktor-zavoda-v-podmoskove-obvinen-v-mahinacijak-s-zemlej.html [Accessed 2 July 2011].

Billette, A. 2009. Apre's une offensive discre`te au Kazakhstan, la Chine lorgne les terres russes inexploite'es [After a quiet aggressive social resistance in Kazakhstan, China is looking for Russian lands]. Le Monde, 20 April. Available from: www.farmlandgrab.org/2917 [Accessed 1 April 2010].

Boldyrev, F. 2001. Roga i kopyta. Pochemu oligarkhi zainteresovalis' sel'skim khozyaistvom

[Horns and hooves. Why oligarchs became interested in agriculture]. Kompaniya, 188(42), $19-22$.

Borras S. Jr., R. Hall, I. Scoones, B. White and W. Wolford. 2011. Towards a better understanding of global land grabbing: an editorial introduction. The Journal of Peasant

Studies, 38(2), 209-216.

Borras, J., R. Hall, I. Scoones, B. White and W. Wolford. 2012. The new enclosures: critical perspectives on land grabbing. Journal of Peasant Studies, 39(3).

Borras, S. Jr., P. McMichael and I. Scoones. 2011. The politics of biofuels, land and agrarian change. London: Routledge.

Brooks, K., E. Krylatykh, Z. Lerman, A. Petrikov and V. Uzun. 1996. Agricultural reform in Russia. A view from the farm level. World Bank Discussion Paper no. 327, Washington,

DC: The World Bank.

BTA Analitika. 2008. Ezhenedelniy obzor/Rynok zemli v Kazakhstane: sostoyanie, tendetsii razvitiy [Weekly review/Land market in Kazakhstan: status and trends]. Available from:

http://www.bta.kz/files/wr_1_december.pdf [Accessed 1 July 2010].

Bush, J. 2008. Farming makes a comeback in Russia. Business Week, 9 October. Available from: www.farmlandgrab.org/2537 [Accessed 20 September 2010].

Cotula, L., S. Vermeulen, R. Leonard and J. Keeley. 2009. Land grab or development opportunity? Agricultural investment and international land deals in Africa. London/Rome: IIED/FAO/IFAD.

D’Hamecourt, P. 2010. Toen Napoleon Maly verliet [When Napoleon left Maly]. Schoorl: Uitgeverij Conserve. 
This article is published by Taylor \& Francis in the Journal of Peasant Studies on 28 May 2012, available online: http://www.tandfonline.com/doi/abs/10.1080/03066150.2012.675574\#.VeCmAPmqqko . To cite this article: Visser, 0 ., N. Mamonova and M.Spoor (2012) 'Oligarchs, megafarms and land reserves: understanding land grabbing in Russia', Journal of Peasant Studies 39:3-4, pp.899-931

Didenko, L. 2009. Pyat' gektarov - I korova, [Five hectares and a cow]. Kommersant Guide, $16(1), 16-17$.

Ding, C. 2007. Policy and praxis of land acquisition in China. Land Use Policy, 24(1), 1-13.

Dronin, N. and A. Kirilenko. 2011. Climate change and food stress in Russia. Regional Environmental Change, 11(1), 167-78.

FAO. 2011. Food security and the transition region. Working paper prepared under the FAO/

EBRD Cooperation for presentation at EBRD’s Grant Planning Meeting. 29 November, London.

Gerasin, S., O. Rodionova and E. Schulze. 2003. On management of agro-industrial complexes, In:

A. Balmann and A. Lissitsa, eds. Large farm management. Bergen/Dumme: AgriMedia, IAMO Studies on the Agricultural and Food Sector in Central and Eastern

Europe, pp. 159-75.

GRAIN. 2008. Seized: The 2008 land grab for food and financial security. Briefing. Available from: http://www.grain.org/briefings/?id1/4212. [Accessed 20 September 2010].

HLPE. 2011. Land tenure and international investments in agriculture. Committee on World

Food Security High Level Panel of Experts on Food Security and Nutrition. REPORT, July.

Rome. Available from: http://www.fao.org/fileadmin/user_upload/hlpe/hlpe_documents/

HLPE-Land-tenure-and-international-investments-in-agriculture-2011.pdf. [Accessed on

27 February 2012].

Hofman, I. and P. Ho. 2012. Journal of Peasant Studies, 39(1).

IAMO. 2011. The agricultural potential of European Russia. F. Schierhorn, K. Hahlbrock and D. Muller. Available from: www.iamo.de [Accessed 25 January 2012].

Ioffe, G. and T. Nefedova. 2004. Marginal farmland in European Russia. Eurasian Geography and Economics, 45(1), 45-59.

Ioffe, G., T. Nefedova and I. Zaslavsky. 2004. From spatial continuity to fragmentation: the case of Russian farming. Annals of the Association of American Geographers, 94(4), 91343.

Ioffe, G., T. Nefedova and I. Zaslavsky. 2006. The end of peasantry? The disintegration of rural Russia. Pittsburgh, PA: University of Pittsburgh Press.

Jouko N. and L. Granberg. 2011. The global food crisis and changes in the Russian agricultural regulation. Paper presented at the International Radboud University/ISS/

MSSES conference: Land accumulation in the former Soviet Union and beyond: Global investors and local communities. 27 October, Moscow, Russia.

Kalb, D. and O. Visser. In press. Oligarchy and state capture: Notes on the Soviet style mechanisms of contemporary finance capitalism. In: J.G. Carrier, ed. A handbook of economic anthropology, second edition. Cheltenham: Edward Elgar publishers. 
This article is published by Taylor \& Francis in the Journal of Peasant Studies on 28 May 2012, available online: http://www.tandfonline.com/doi/abs/10.1080/03066150.2012.675574\#.VeCmAPmqqko . To cite this article: Visser, 0 ., N. Mamonova and M.Spoor (2012) 'Oligarchs, megafarms and land reserves: understanding land grabbing in Russia', Journal of Peasant Studies 39:3-4, pp.899-931

Kalugina, Z. and O. Fadeeva. 2009. Rossiiskaya derevnya v labirinte reform. Sotsiologicheskie zarisovki [Russian village in the labyrinth of land reforms]. Novosibirsk: Institut Ekonomiki i Organizatsii Promyshlennogo Proizvodstva Sibirskogo otdeleniya RAN

[Institute of Economics and Industrial Production Management of Sibirian department of Russian Academy of Science].

Kandell, J. 2009. Betting on the Russian farm. Institutional investor. Available from: http:// farmlandgrab.org/13810 [Accessed 1 April 2011].

Kozyrev, M. and M. Abakumova. 2008. Zona riskovannogo zemlevladeniya [Zone of risky land tenure]. Journal Forbes. Available from: http://www.lobbying.ru/content/sections/articleid_3770_linkid_58.html [Accessed 11 October 2010].

Lerman, Z. and N. Shagaida. 2007. Land policies and agricultural land markets in Russia. Land Use Policy, 24, 14-23.

Lindner, P. 2008. Der Kolchoz-Archipel im Privatisierungsprozess: Wege und Umwege der

russischen Landwirtschaft in die globale Marktgesellschaft [The collective farms in the archipelago- privatization process: paths and detours of the Russian agriculture in the global market society]. Bielefeld: Deutsche Forschungsgemeinschaft.

Luchev, N. 2009. Interview of the CEO of Agro-Invest Brinky Willeke van den Brink, Journal Agroinvestor 11. Available from: http://www.agro-investor.ru/issue/75/5251/ [Accessed 20 December 2010].

Moskalkova, T. 2011. Zemelnaya i sovdovodcheskaya mafiya [Land and garden mafia]. Available from: www.souzsad.ru/index.php/gl/39-sgt/60-2011-01-26-19-51-51 [Accessed 10 October 2010].

Nikulin, A. 2005. Noveichaya gigantomaniya [New gigantomania]. Politichesskii

Zhurnal, 63 (12). Available from: http://www.politjournal.ru [Accessed 25 January 2012].

Nikulin, A. 2010. Oligarkhoz kak preemnik postkolkhoza. Ekonomischeskaya Sotsiologiya, 11 (1), 17-33. Available from www.ecsoc.msses.ru [Accessed 5 February 2012].

Pallot, J. and T. Nefedova. 2007. Russia's unknown agriculture: household production in postsocialist rural Russia. Oxford: Oxford University Press.

Peluso, N. L. and C. Lund. 2011. New frontiers of land control: introduction. Journal of Peasant Studies, 38(4), 667-81.

Poshkus B. 2009. Stanovlenie rinochnih otnosheniy v selskom khoziaystve [Creation of market relationships in Russian agriculture]. Moscow: VIAPI Press.

Prishchepov, A., V. Radeloff, M. Dubinin and C. Alcantara. Forthcoming. The effect of satellite image dates on land-cover change detection and the mapping of agricultural land abandonment in Eastern Europe. Remote Sensing of Environment.

Rambler Media Group. 2007. V Moskve arestovan zastroyschik kurortnoy zoni Ruzskaya Shveytsariya [The developer of the resort Ruza Switzerland was arrested in Moscow]. Lenta.Ru/News. Posted 26 February. Available from: http://lenta.ru/news/2007/02/26/

Boiko/ [Accessed 10 October 2010]. 
This article is published by Taylor \& Francis in the Journal of Peasant Studies on 28 May 2012, available online: http://www.tandfonline.com/doi/abs/10.1080/03066150.2012.675574\#.VeCmAPmqqko . To cite this article: Visser, O., N. Mamonova and M.Spoor (2012) 'Oligarchs, megafarms and land reserves: understanding land grabbing in Russia', Journal of Peasant Studies 39:3-4, pp.899-931

Report of Arbitration Court of Bashkortostan Republic. 2008. Obobschenie sudebnoy praktiki

po rassmotreniyu sporov sviazannih s primeneniem sudebnogo zakonodatelstva za 2007 god I za 1 polugodie 2008 goda [Generalization of court practice in the consideration of disputes involving the use of land laws in 2007 and for the 1st half of 2008]. Available from: http://ufa.arbitr.ru/pract/2961.html [Accessed 20 November 2010].

Rosenberg, M. 2012. Population decline in Russia. Available from: http://geography.about.com/od/obtainpopulationdata/a/russiapop.htm [Accessed 27 January 2012].

Rosreestr (Federal Service for State Registration, Cadastre and Cartography). 2010. State (national) report on the status and use of land in the Russian Federation in 2009. Available from: http://slon.ru/documents/doklad_ob_ispolzovanii_zemel_2008.pdf [Accessed 21 November 2011].

Rosstat (Federal State Statistics Service). 2006. Vserossiyskaya selskokhoziaystvennaya perepis

2006. Part 3. Zemelnie ressursi $\mathrm{i}$ ih ispolzovanie. [The outcome of the All-Russian Agricultural Census of 2006, Book 3: Land resources and their use]. Available from: http://www.gks.ru/news/perepis2006/T3/tabl_t3.pdf [Accessed 10 October 2010; 20

November 2011].

Shagaida, N. 2005. Living with constraints: Russia's agricultural land market. BASIS Brief, 36(10), $1-4$.

Solomatina O. 2007. Zolotaya sotka [Golden hectares]. Available from: http://moszem.ru/text/1180045737.html [Accessed 1 November 2011].

Spoor, M. and O. Visser. 2001. The state of agrarian reform in the FSU. Europe-Asia Studies (former Soviet Studies), 5(6), 885-901.

Spoor, M. and O. Visser. 2004. Restructuring postponed? Large Russian farm enterprises 'coping with the market'. Journal of Peasant Studies, 32(2), 515-51.

Starobin, P. and C. Belton. 2002. Russia's new wealth. Business Week 5 August. Available from: www.businessweek.com/print/magazine/content/02_31/b3794013.htm?chan1/4mz [Accessed 1 March 2010].

Tarrow, S. 1998. Power in movement: social movements and contentious politics. Cambridge: Cambridge University Press.

The Federal Law N 136-FZ 'Land Code of Russian Federation', article 284 (2001). Available from: www.souzsad.ru/index.php/gl/39-sgt/60-2011-01-26-19-51-50 [Accessed 27 January 2011].

Uzun, V. 2005. Large and small business in Russian agriculture: adaptation to market.

Comparative Economic Studies, 47(1), 85-100.

Uzun, V. 2011. Klassificatsiya selhozproizvoditeley Rossii i agrarnaya strukltura regionov [Classification of agricultural producers in Russia and agrarian structure of its regions]. Paper presented at the Guidar Forum. 18 March, Moscow. 
This article is published by Taylor \& Francis in the Journal of Peasant Studies on 28 May 2012, available online: http://www.tandfonline.com/doi/abs/10.1080/03066150.2012.675574\#.VeCmAPmqqko . To cite this article: Visser, O., N. Mamonova and M.Spoor (2012) 'Oligarchs, megafarms and land reserves: understanding land grabbing in Russia', Journal of Peasant Studies 39:3-4, pp.899-931

Uzun, V., E. Gataulina, V. Saraikin, V. Bashmachnikov, O. Pavlushkina and O. Rodionova. 2009. Tendentsii razvitiya i mekhanizmy vzaimodeistviya kruphnogo i malogo biznesa $\mathrm{v}$ agropromyshlennom komplekse [Trends in the development and mechanisms of interaction large and small businesses in the agricultural sector]. Moscow: VIAPI Press.

Vasilyeva, N. 2008. Russian farming: from basket case to breadbasket? Associated Press 19 September 2008. Available from: www.farmlandgrab.org/2514 [Accessed 20 September 2010].

Visser, O. 2006. Property, labour relations and social obligations in Russia's privatised farm enterprises. In: K. von Benda-Beckman, F. von Benda-Beckman and M.G. Wiber, eds. The changing properties of property. London, New York: Berghahn, pp. 126-46.

Visser, O. 2008. Crucial connections: the persistence of large farm enterprises in Russia. PhD Thesis, Department of Anthropology and Development Studies, Radboud University Nijmegen.

Visser, O. 2009. Household plots and the symbiosis with the large farm enterprises. In: M. Spoor, ed. Land, peasants and rural poverty in transition: the political economy of rural livelihoods in transition economies. Studies in Rural Livelihoods Series. London, New York: Routledge.

Visser, O. 2010. Rights over land and obstacles to family farming in Russia: a comparison with Argentina. Laboratorium, 1(2), 420-4.

Visser, O. and D. Kalb. 2010. Financialised capitalism Soviet style? Variants of state capture and crisis. Archives Europeennes de Sociology, L(2), 171-94.

Visser, O. and N. Mamonova. 2011. Emerging rural movements in Russia. Genuine movements or virtual vehicles with concealed aims? Paper presented at the master class: Social Movements in the South: how to study and write about them. Wageningen School of Social Sciences, 27 May, Wageningen University.

Visser, O. and M. Spoor. 2011a. Land grabbing in post-Soviet Eurasia: the world's largest land reserves at stake. The Journal of Peasant Studies, 38(2), 299-324.

Visser, O. and M. Spoor. 2011b. Land governance in post-Soviet Russia: conflict and cooperation between local authorities and agroholdings. Paper presented at the ISS/

Cornell workshop Comparative Land Institution, January 20-21, Institute of Social Studies (ISS), The Hague.

von Benda-Beckmann, F. 2003. Mysteries of capital or mystification of legal property? FocaalJournal of Global and Historical Anthropology, 41, 187-91.

von Benda-Beckmann, F., K. von Benda-Beckmann and M.G. Wiber, eds. 2006. Changing properties of property. London, New York: Berghahn.

von Braun, J. and R. Meinzen-Dick. 2009. 'Land grabbing' by foreign investors in developing countries: risks and opportunities. Policy Briefs 13. Washington, DC: International Food 
This article is published by Taylor \& Francis in the Journal of Peasant Studies on 28 May 2012, available online: http://www.tandfonline.com/doi/abs/10.1080/03066150.2012.675574\#.VeCmAPmqqko . To cite this article: Visser, O., N. Mamonova and M.Spoor (2012) 'Oligarchs, megafarms and land reserves: understanding land grabbing in Russia', Journal of Peasant Studies 39:3-4, pp.899-931

Policy Research Institute (IFPRI).

Wegren, S. 2007. The State and agricultural reform in post-communist Russia. Journal of Peasant Studies, 34(3), 498-526.

Wegren, S. 2009a. Russian agriculture in 2009: continuity or change? Eurasian Geography and Economics, 50(4), 464-79.

Wegren, S. 2009b. Russia's incomplete land reform. Russian Analytical Digest, 64(09), $2-5$.

Wegren, S. 2010. Russian Agriculture in the Late Putin Period and Beyond, in: S. Wegren and Dale R. Herspring (eds.) After Putin's Russia: Past Imperfect, Future Uncertain. Landham, MD: Rowman and Littlefield, pp. 199-222.

Wegren, S. 2011. Food security and Russia's 2010 drought. Eurasian Geography and Economics, 52(1), 140-56.

Winter, S. 2012. Pigs and protection money: German farmers seek their fortunes in Russia.

Der Spiegel. Posted 12 January. Available from: www.farmlandgrab.org/post/view/19872 [Accessed 12 January 2012].

World Bank. 1992. Food and agricultural policy reforms in the former USSR: an agenda for transition. Studies in Economies in Transformation, no. 1. Washington, D.C.: The World Bank.

World Bank. 2010a. Rising global interest in farmland. Can it yield sustainable and equitable benefits? Washington, D.C.: The World Bank.

World Bank. 2010b. Online database, section: Arable land (hectares per person) 2005-2009 Available from: http://data.worldbank.org/indicator/AG.LND.ARBL.HA.PC/countries, [Accessed 12 October 2010].

Zaslavskaya, O. 2010. Ekoniva-agro revives cattle breeding in Liski district. Ekonomika i Zhizn' Chernozemie newspaper, 7(30), 10-23.

Zimin, B. 2010. Promoting investment in Russia's regions. Eurasian Geography and Economics, 51(5), 653-68.

Zoomers, A. 2010. Globalization and the foreignization of space: seven processes driving the current land grab. Journal of Peasant Studies, 37(2), 429-47.

Oane Visser is Assistant Professor in Anthropology and Development Studies at Radboud University Nijmegen, the Netherlands. His research focuses on land grabbing, poverty and social movements in Eastern Europe and the former Soviet countries. He has published in journals including Europe-Asia Studies, Focaal - Journal of Global and Historical 
This article is published by Taylor \& Francis in the Journal of Peasant Studies on 28 May 2012, available online: http://www.tandfonline.com/doi/abs/10.1080/03066150.2012.675574\#.VeCmAPmqqko . To cite this article: Visser, O., N. Mamonova and M.Spoor (2012) 'Oligarchs, megafarms and land reserves: understanding land grabbing in Russia', Journal of Peasant Studies 39:3-4, pp.899-931

Anthropology and the European Journal of Sociology. Recently he published, with Don Kalb, on the financial crisis, financialised capitalism in the West and the unexpected similarities with the Soviet planned economy. He published with Max Spoor the first exploratory study of land grabbing in post-Soviet Eurasia (Journal of Peasant Studies, 2011). Corresponding author E-mail: o.visser@maw.ru.nl

Natalia V. Mamonova is a $\mathrm{PhD}$ candidate at the International Institute of Social Studies (ISS) of Erasmus University Rotterdam and at Radboud University Nijmegen, the Netherlands. Her doctoral research focuses on land grabbing in the post-Soviet countryside, and on land conflicts and rural social movements in Russia and Ukraine. She worked as a research associate at Radboud University Nijmegen in 2010-2011 under the supervision of Dr. Oane Visser. The projects she was involved in are 'Land grabbing in Russia' (2010, LDPI grant) and 'Large-scale land acquisition in the FSU' (2011, LANDac grant). E-mail: mamonova@iss.nl

Max Spoor is Professor of Development Studies at the International Institute of Social Studies, The Hague/Erasmus University Rotterdam. His research focuses on rural and environmental issues, poverty, and inequality in Asian transition economies, Central Eastern Europe and former Soviet Central Asia. His most recent books are The political economy of rural livelihoods in transition economies (Routledge, 2009) and, with Murat Arsel, Water, environmental security and sustainable rural development: conflict and cooperation inCentralEurasia (Routledge, 2010). Together with Oane Visser he published the first exploratory study of land grabbing in post-Soviet Eurasia (Journal of Peasant Studies, 2011). Email: spoor@iss.nl 
